Linköping University Medical Dissertation

No. 1642

\title{
Formation and Relevance of Platelet Subpopulations
}

Anna Södergren

DIU UNIVERING

Department of Clinical and Experimental Medicine Faculty of Medicine and Health Sciences

Linköping University

Linköping 2018 
During the course of the research underlying this thesis, Anna Södergren was enrolled in Forum Scientium, a multidisciplinary doctoral program at Linköping University, Sweden

\section{Formation and Relevance of Platelet Subpopulations}

Anna Södergren

Linköping University Medical Dissertation No. 1642

ISBN: 978-91-7685-215-6

ISSN: 0345-0082

(C) Anna Södergren, 2018, unless otherwise stated.

Cover: A flow cytometry histogram (adapted). Created by the author.

Published papers and figures have been reprinted with permission from the respective publishers or in accordance with the creative commons license 4.0 Printed by LiU-Tryck, Linköping, Sweden, 2018. 
Mamma, min förebild och hjälte Alfons, min solstråle 



\section{Abstract}

Platelets are important players in the hemostatic system, acting as guardians of vessel integrity. When they come across a breach in the vessel wall, they quickly adhere to the damaged surface, secrete activating and adhesive compounds from their secretory granules, recruit additional platelets into a growing platelet plug and support the action of the coagulation system. In the past decades, it has become clear that platelets form functionally different platelet subpopulations. The aggregatory platelets build the platelet plug, whereas the procoagulant subpopulation support and direct the actions of the coagulation system. The aim of this thesis was to examine the formation and features of the different platelet subpopulations, and elucidate their respective roles in hemostasis.

Platelet lysosomal secretion is not well characterized. In Paper I, we found that lysosomal secretion, detected as LAMP-1 surface exposure, occur upon potent platelet stimulation including secondary activation by ADP. This is regulated by the endothelial platelet inhibitors nitric oxide and prostacyclin. As observed in Paper II, lysosomal secretion might also be of clinical relevance as a quality indicator for platelet concentrates used for transfusion, an area were quality control may become increasingly important in the future. Among several evaluated platelet activation markers, platelet LAMP-1 exposure and the ability to form procoagulant platelets may be useful as novel indicators of platelet responsiveness. Moreover, the ability to form procoagulant platelets varies extensively between individuals, something we established in Paper III. Here we also present a novel flow cytometry protocol enabling the simultaneous investigation of 6 different platelet activation markers. Using this protocol we investigate the formation of procoagulant platelets and reveal that only a subpopulation of platelets may become procoagulant. Further we show that this is dependent on the agonist stimulation applied. Finally in Paper IV, we explore the influence of the procoagulant platelet subpopulation on different aspects of hemostasis. While platelet aggregation was not affected, the fraction of procoagulant platelets was found to strongly correlate to peak thrombin generation, and to be associated with plasma cholesterol levels.

In conclusion, this thesis presents evidence for the use of LAMP-1 surface exposure and the formation of a procoagulant platelet subpopulation as potential indicators of platelet activation potential. The formation of procoagulant platelets varies extensively between individuals, influence hemostasis and is associated with the known risk factor cholesterol. Thus, the formation of a procoagulant platelet subpopulation may be a candidate biomarker for cardiovascular disease, to be explored in the future. 


\section{Populärvetenskaplig sammanfattning}

Blodet som med hjälp av hjärtat flödar i våra blodkärl levererar syre och näringsämnen till kroppens alla celler och vävnader. Att bibehålla blodflödet är livsviktigt och redan kortvariga uppehåll kan få allvarliga konsekvenser, såsom vid hjärtinfarkt eller stroke. Blodtillförseln påverkas bland annat av blödningar till följd av skador. Således har kroppen genom tusentals år utvecklat ett komplicerat system som kallas hemostasen. Hemostasen har till uppgift att täppa till hål i våra blodkärl för att minska blodförlusten och på så vis upprätthålla blodtillförsel till våra organ.

Hemostasen brukar delas upp i två delar. Den ena delen består av blodplättar, eller trombocyter som de också kallas, vilka är små celler i blodet. Den andra delen utgörs av koagulationskaskaden, och innefattar klyvning och aktivering av en rad proteiner. När en skada uppstår på ett blodkärl samverkar de båda delarna för att stoppa blödningen. Trombocyterna fungerar som blodkärlens väktare och fastnar snabbt på den skadade ytan. När de fastnat lockar de till sig ytterligare trombocyter från blodet. Trombocyterna klumpar ihop sig till en trombocytplugg, som likt en diskpropp kan täppa igen hålet i kärlet. Skadan på blodkärlet aktiverar också koagulationskaskaden. Koagulationskaskaden fungerar genom att det ena proteinet i kaskaden aktiverar nästa i en lång kedja, som avslutas genom att ett protein som heter trombin klyver fibrinogen till fibrin. Fibrin bildar då en sorts armeringsnät som stärker trombocytpluggen och ser till att proppen sitter kvar tills det att skadan läkt. Det är viktigt att hemostasen är rätt balanserad. Om trombocyterna eller koagulationskaskaden inte är tillräckligt effektiva, finns risk att blödningen inte slutar, eller börjar igen. Om dessa däremot är för effektiva finns risk att kärlet täpps igen helt och därmed hindrar blodflödet till de kroppsdelar som ligger längre ned längs blodkärlet.

Under de senaste decennierna har man kartlagt hur koagulationskaskaden och trombocyterna samverkar och upptäckt att olika trombocyter har olika uppgifter i hemostasen. En grupp (subpopulation) av trombocyter är bra på att klumpa ihop sig, medan andra genom att ändra sin yta underlättar och dirigerar koagulationskaskaden.

Under det här avhandlingsarbetet har jag ägnat mig åt att studera hur de olika subpopulationerna av trombocyter bildas, vad som kännetecknar dem och vilken roll de har i hemostasen. Vi har sett att den subpopulation som underlättar koagulationen, bara bildas då trombocyterna blir starkt aktiverade, såsom vid större kärlskador, samt att andelen som kan skapas varierar mellan olika människor. Slutligen visar vi att andelen som bildas är viktig för hur mycket trombin som kan bildas. Arbetet som ligger till grund för den här avhandlingen visar att bildandet av subpopulationer av trombocyter skulle kunna vara en intressant markör för att undersöka vilka individer som löper risk att drabbas av hjärt- och kärlsjukdomar. 


\section{List of papers}

\section{Paper I}

Thrombin-induced lysosomal exocytosis in human platelets is dependent on secondary activation by ADP and regulated by endothelial-derived substances

Anna Södergren*, Ann-Charlotte Svensson Holm*, Sofia Ramström, Eva Lindström, Magnus Grenegård, \& Karin Öllinger

Platelets 2016;27: 86-92.

\section{Paper II}

Responsiveness of platelets during storage studied with flow cytometry formation of platelet subpopulations and LAMP-1 as new markers for the platelet storage lesion

Anna Södergren, Nahreen Tynngård, Gösta Berlin \& Sofia Ramström

Vox Sanguinis 2016;110:116-25.

\section{Paper III}

Platelet subpopulations remain despite strong dual agonist stimulation and can be characterised using a novel six-colour flow cytometry protocol

Anna Södergren \& Sofia Ramström

Scientific Reports 2018;8:1441.

\section{Paper IV}

The effect of procoagulant platelets on different aspects of haemostasis

Anna Södergren \& Sofia Ramström

Manuscript.

* These authors contributed equally. 


\section{List of papers outside of the thesis}

Platelet adhesion changes during storage studied with a novel method using flow cytometry and protein-coated beads

Nahreen Tynngård, Maria Wallstedt, Anna Södergren, Lars Faxälv, \& Sofia Ramström

Platelets 2015;26: 177-85.

Platelet Function Determined by Flow Cytometry: New Perspectives?

Sofia Ramström, Anna Södergren, Nahreen Tynngård, Tomas Lindahl

Seminars in Thrombosis \& Hemostasis 2016;42: 268-81.

Detection of Lysosomal Exocytosis in Platelets by Flow Cytometry.

Anna Södergren, Sofia Ramström

Methods in Molecular Biology 2017;1594: 191-203. 


\section{Table of contents}

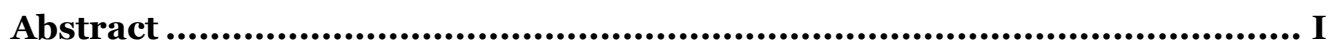

Populärvetenskaplig sammanfattning......................................................III

List of papers ..............................................................................

Table of contents........................................................................................ VII

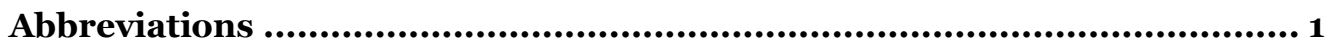

Introduction ......................................................................................... 3

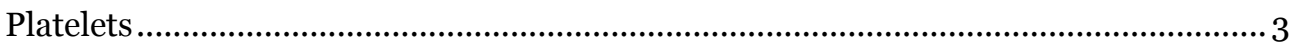

Platelet structure and organelles........................................................................... 4

Platelet receptors ............................................................................................... 5

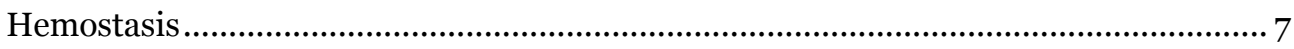

Primary hemostasis ..........................................................................................

Secondary hemostasis .........................................................................................

Localization of hemostasis ...................................................................................11

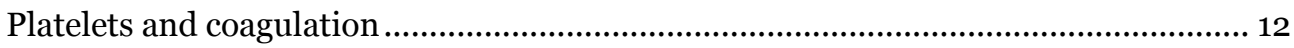

The plasma membrane ........................................................................................... 12

Description of the procoagulant platelet.................................................................. 12

Procoagulant platelets and agonists.................................................................. 14

Procoagulant platelets and calcium ................................................................. 15

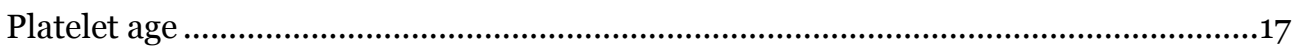

Platelet concentrates...........................................................................................

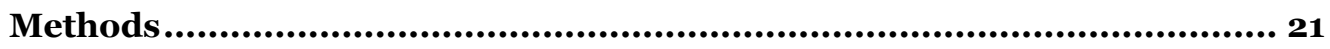

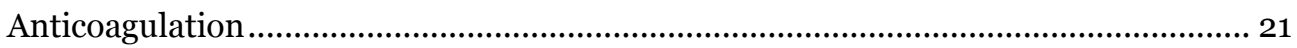

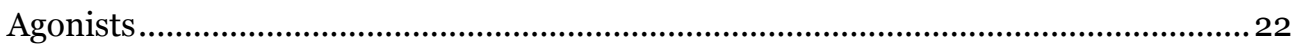

Light transmission aggregometry ..................................................................... 22

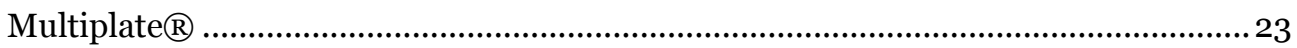

Calibrated automated thrombogram........................................................................ 24

Free oscillation rheometry............................................................................... 25

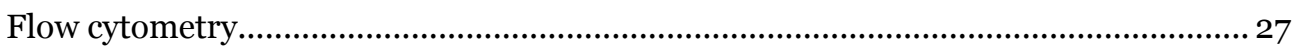

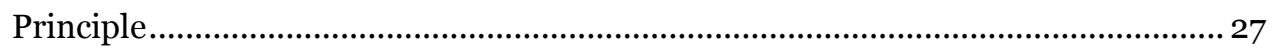

Flow cytometry and considerations for development of the 6-colour protocol........28

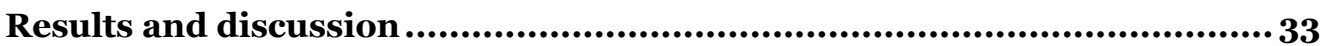




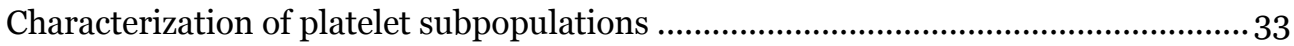

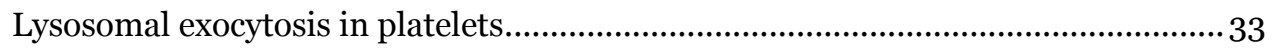

Procoagulant platelets (features of procoagulant and aggregatory platelets)..........34

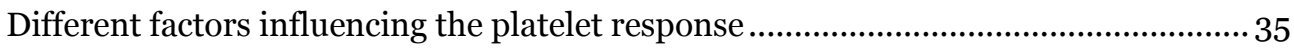

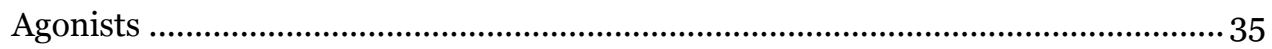

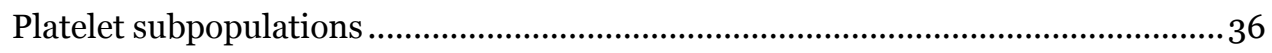

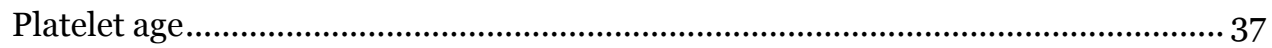

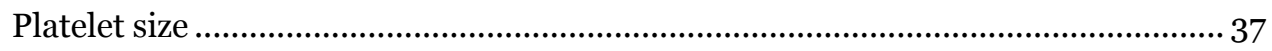

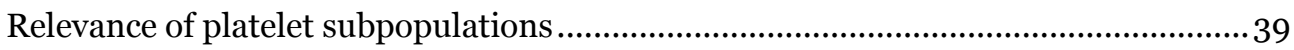

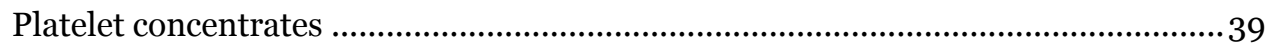

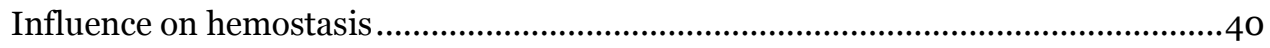

My view on platelet subpopulations in clot formation ..........................43

Conclusion ..................................................................................46

Acknowledgements .................................................................... 47

References ...................................................................................49 


\section{Abbreviations}

\begin{tabular}{|c|c|}
\hline ACD & Acid citrate dextrose \\
\hline ASA & Acetylsalicylic acid \\
\hline $\mathrm{Ca}^{2+}$ & Calcium \\
\hline $\mathrm{Cl}^{-}$ & Chloride \\
\hline CAT & Calibrated automated thrombogram \\
\hline $\mathrm{CCCP}$ & Carbonyl cyanide 3- chlorophenylhydrazone \\
\hline COX-I & Cyclooxygenase I \\
\hline CRP-XL & Cross-linked collagen-related peptide \\
\hline $\mathrm{DiIC}_{1}(5)$ & $1,1^{\prime}, 3,3,3^{\prime}, 3^{\prime}$-hexamethylindodicarbocyanine iodide \\
\hline DTS & Dense tubular system \\
\hline ECM & Extracellular matrix \\
\hline ETP & Endogenous thrombin potential \\
\hline $\mathrm{F}$ & Coagulation factor (FII, FV, FVII etc.) \\
\hline FITC & Fluorescein isothiocyanate \\
\hline FMO & Fluorescence-minus-one \\
\hline FOR & Free oscillation rheometry \\
\hline GP & Glycoproteins \\
\hline GPCR & G-protein coupled receptors \\
\hline LAMP & Lysosomal-associated-membrane protein \\
\hline LTA & Light transmission aggregometry \\
\hline MFI & Median fluorescence intensity \\
\hline mPTP & Mitochondrial permeability transition pore \\
\hline MPV & Mean platelet volume \\
\hline $\mathrm{Na}^{+}$ & Sodium \\
\hline NAG & $N$-actetyl- $\beta$-glucosaminidase \\
\hline NO & Nitric oxide \\
\hline PAR & Protease activated receptor \\
\hline PAR-AP & Protease activated receptor activating peptide \\
\hline PGI2 & Prostacyclin \\
\hline PRP & Platelet-rich plasma \\
\hline PS & Phosphatidylserine \\
\hline SCIP & Sustained intracellular calcium induced platelet morphology \\
\hline SNAP & S-Nitroso- $N$-acetyl-DL penicillamine \\
\hline SOCE & Store-operated calcium entry \\
\hline TAFI & Thrombin activatable fibrinolysis inhibitor \\
\hline $\mathrm{TF}$ & Tissue factor \\
\hline TFPI & Tissue factor pathway inhibitor \\
\hline TO & Thiazole orange \\
\hline TRPC & Transient receptor potential canonical \\
\hline TxA2 & Thromboxane $\mathrm{A}_{2}$ \\
\hline vWF & von Willebrand factor \\
\hline
\end{tabular}




\section{Introduction}

The blood that circulates in our arteries and veins consists of plasma, which is the fluid part of the blood, and different cells; red blood cells, white blood cells and platelets. Among other things the blood delivers oxygen and nutrients to all cells of the body, and transports waste products to the liver and kidneys. Due to these crucial tasks, it is absolutely vital that the blood continues to flow through our vessels. Maintaining the blood flow is the role of the hemostatic system. If the blood supply is compromised by excessive bleeding following injury or vessel occlusion from inappropriate blood clot formation, the survival of the affected tissue or the entire body is endangered. Disorders coupled to hemostasis are serious and common, in 2016 they were responsible for approximately $1 / 3$ deaths in Sweden, making them the most common cause of death [1].

\section{Platelets}

Platelets serve several functions in the body, but their primary function is to detect damages to the blood vessels and sealing these to stop bleeding. They circulate in the blood in a quiescent state at a concentration of $125-400 \times 10^{9} /$ l. Platelets are discoid in shape with a diameter around $2-5 \mu \mathrm{m}$ and a volume of $6-10 \mathrm{fl}$, as such they are the smallest cells, or rather cell fragments, of the blood [2-4]. Platelets are anucleate and have a limited possibility of protein synthesis [3]. Due to their small size, they circulate at the periphery of the blood vessels, where they may quickly detect and act upon a vessel damage [5]. Platelets have a life span of up to 10 days in circulation $[3,4,6]$ and they may be regarded as disposable or one-time use cells. Platelets are formed from megakaryocytes in the bone marrow, where each megakaryocyte may generate 1500-3000 platelets [3]. There are however indications that platelet production may also take place in other tissues, primarily in the lung [7, 8]. Megakaryocytes normally form long protrusions, called proplatelets [8]. These start out as thick pseudopodia but thin and elongate as they form. The proplatelets extend into the blood vessels where sections bud off as individual platelets or as larger proplatelet extensions, which then divide further into single platelets in the circulation or lung. It is highly likely that the budding process is partly dependent on shear forces in the blood vessel. Under normal conditions, the predominant process for platelet production is via the extension of proplatelets. During inflammation or situations of platelet depletion, platelet production can also occur via megakaryocyte rupture [9]. This leads to a faster release of platelets with a slightly increased size, but with the consequence of a somewhat reduced life span and slightly impaired function. 


\section{Platelet structure and organelles}

\section{Membrane}

The platelet membrane consists of a regular phospholipid bilayer, where the neutral phospholipids phosphatidylcholine and sphingomyelin are located in the outer leaflet, while phosphatidylserine (PS), phosphatidylethanolamine and phosphoinositide are located in the inner leaflet. This asymmetry is maintained in resting platelets but may be disrupted upon platelet activation (see section Platelets and coagulation) [10]. The plasma membrane is covered by glycolipids, oligosaccharides, glycoproteins (GP) and proteoglycan side chains which make up an extracellular coat called the glycocalyx. In addition, the plasma membrane has many connections to the open canalicular system (OCS). The open canalicular system serves as a membrane reserve, which along with the membrane of the secreted granules (primarily a-granules) are crucial for platelet spreading. As the open canalicular system has several openings towards the plasma membrane, it may also serve as a transport system for substances entering or leaving the platelet $[2,4,5]$.

\section{Cytoskeleton}

The platelet cytoskeleton is built from three cytoskeletal components. Beneath the plasma membrane is a membrane skeleton consisting of a spectrin mesh, which is anchored to GPs, mainly GPIb, in the plasma membrane with the help of short actin filaments. Along the short end of the platelet disc, a marginal band formed by microtubular coils is located. Finally, long actin filaments extend from the center of the platelet to the outer cytoskeleton. The spectrin mesh is important for maintaining membrane integrity, whereas the actin and microtubular coils are thought to be responsible for the discoid shape of the platelet. It should be recognized that the cytoskeleton also contains a myriad of cytoskeletal proteins important for the exertion of different functions. The platelet cytoskeleton is highly dynamic, which is important to allow platelet shape change, extension of filopodia and platelet spreading upon activation $[2,5,11]$.

\section{Dense tubular system}

The dense tubular system (DTS) is situated in close proximity to the open canalicular system within the platelet. It resembles the sarcoplasmic reticulum found in muscle cells. The main role of the DTS is to store and upon activation release calcium $\left(\mathrm{Ca}^{2+}\right)$ into the cytosol. Cyclooxygenase I (COX-I) activity responsible for the generation of thromboxane A2 (TxA2) can also be detected in the DTS $[2,5]$.

\section{a-granules}

$\alpha$-granules are the most abundant of the secretory granules, with 50-80 $\alpha$-granules per platelet. The contents of the $\alpha$-granules are produced by the megakaryocyte or taken up by the megakaryocyte or platelet through endocytosis. Endocytosed proteins found in the a-granule include fibrinogen and coagulation factor (F) V. $\alpha$ granules contain both membrane proteins, where $\alpha \mathrm{IIb} \beta 3$ and P-selectin (CD62P) 
are perhaps the most important, and a vast number of soluble proteins. Proteins released from the a-granules include hemostatically important proteins like fibrinogen, von Willebrand factor (vWF), thrombospondin, FV, FIX, FXIII and anticoagulation factors. In addition, proteins involved in tissue repair, angiogenesis, inflammation and host defense are released [12].

\section{Dense granules}

Platelets contain 3-8 dense granules each. These contain small molecules such as ADP, ATP, $\mathrm{Ca}^{2+}$, and serotonin, which are important in secondary activation of platelets. The membrane of dense granules contain integral proteins like lysosomal-related proteins, lysosomal-associated-membrane protein (LAMP)-2 and CD63, as well as GPIb and $\alpha \operatorname{IIb} \beta 3$ [12].

\section{Lysosomes}

Platelets contain up to three lysosomes. The lysosomes contain degrading proteins of different kinds, such as glucosaminidase, cathepsins, and acid phosphatase. Integral proteins include LAMP-1, LAMP-2 and CD63 [12, 13]. Platelet lysosomes are important for the degradation of cellular components and during autophagy, which becomes enhanced during platelet activation [5]. The function of lysosomal secretion is however not known. It has been speculated that lysosomal secretion play a role in fibrinolysis, remodeling of the extracellular matrix and cleavage of membrane receptors $[5,13]$. Increased exposure of LAMP-1 has also been found on the surface of cells with increased adhesive potential, which might infer an adhesive role also in platelets [14]. Secretion of lysosomal contents may also be beneficial in host defense against microbes [15].

\section{Platelet receptors}

The platelets have a large set of receptors on their surface. These function to anchor the cells to the surface, and to respond to different activating or inhibiting substances. Some of these receptors, important for this thesis, are described below.

\section{GPIb-IX-V}

GPIb-IX-V is present in approximately 50 ooo copies/platelet. It is the main vWF receptor on platelets. GPIb-IX-V-vWF interactions are crucial for platelet adhesion under conditions of high shear stress. In addition to vWF, GPIb-IX-V may also bind other ligands, e.g. thrombin, thrombospondin, present in the extracellular matrix (ECM) or bound to activated platelets via $\alpha \mathrm{IIb} \beta 3$, P-selectin, which is expressed by activated endothelial cells and Mac-1 present on leukocytes. Deficiency in GPIb or GPIX results in the bleeding disorder Bernard-Soulier syndrome [16-19].

\section{$\alpha \operatorname{llb} \beta 3$}

$\alpha \mathrm{IIb} \beta 3$ (GPIIb/IIIa) integrin is the most abundant platelet receptor, present in $50000-80000$ copies/platelet, with additional copies in the platelet granules. $\alpha \operatorname{IIb} \beta 3$ is the receptor responsible for platelet aggregation, and may also participate in platelet adhesion. It binds proteins with an RGD-motif; fibrinogen, 
vWF, thrombospondin, fibronectin and vitronectin. On resting platelets, $\alpha \operatorname{IIb} \beta 3$ is present in a low-affinity state. Upon platelet activation and inside-out signaling, $\alpha I I b \beta 3$ will take on a high affinity state. Binding and activation of the receptor results in platelet spreading, aggregation and clot retraction, as well as activation of other platelet integrins [19]. Absence or deficiency in $\alpha \operatorname{IIb} \beta 3$ is the cause of the bleeding disorder Glanzmann's thrombasthenia. [19, 20].

$\alpha 2 \beta 1$

$\alpha 2 \beta 1$ (GPIa/IIa) is present in 2000-4000 copies/platelet. It binds to collagen and upon activation it participates in platelet adhesion to collagen $[16,18,19]$.

GPVI - FC $\gamma R$

GPVI is a member of the immunoglobulin family, present in $4000-6000$ copies/platelet. It is a collagen receptor which couples to the immune receptor $\mathrm{Fc} \gamma \mathrm{R}$ also present on platelets. Receptor ligation and crosslinking leads to platelet activation via ITAM-induced tyrosine phosphorylation and activation of phospholipase Cy2 (PLCy2). This causes integrin activation, granule secretion and an increase in intracellular $\mathrm{Ca}^{2+}[18,19,21,22]$. Activation of GPVI is also highly important for the exposure of procoagulant phosphatidylserine [23-25].

\section{PARS}

Protease activated receptor (PAR) -1 and PAR4 are thrombin receptors, of which PAR1 is the most sensitive to thrombin. They are activated through a special mechanism in which thrombin cleaves the $\mathrm{N}$-terminal of the inactive receptor, generating a new $\mathrm{N}$-terminal. This new $\mathrm{N}$-terminal will bind to the active site of the receptor resulting in autoactivation. PAR1 and PAR4 are both G-protein coupled receptors (GPCR) coupling to G12/13 and Gq, where their respective activation result in platelet shape change, granule release, $\mathrm{Ca}^{2+}$ mobilization and integrin activation. Despite similar activation pathways, $\mathrm{Ca}^{2+}$ mobilization from PAR1 and PAR4 differ somewhat, where PAR1 results in fast $\mathrm{Ca}^{2+}$ spikes while PAR4 results in a slower but prolonged $\mathrm{Ca}^{2+}$ response[26].

TP

The prostanoid TP-receptor responds to activation by TxA2, which is important to reinforce platelet activation by other agonists. The TP receptor couples to $\mathrm{Gq}$ and G13 to induce an increase in intracellular $\mathrm{Ca}^{2+}$ and platelet shape change. TxA2 production is a common anti-platelet target, where COX-I is inhibited by acetylsalicylic acid (ASA) [16, 27].

\section{P2Y1 and P2Y12}

Platelets have two major ADP receptors, $\mathrm{P} 2 \mathrm{Y} 1$ and $\mathrm{P} 2 \mathrm{Y} 12$, where $\mathrm{P} 2 \mathrm{Y} 12$ is the more abundant. The role of $\mathrm{P} 2 \mathrm{Y} 1$ and $\mathrm{P} 2 \mathrm{Y} 12$ is, similar to the TP receptor, to reinforce platelet activation induced by other agonists having caused dense granule release. $\mathrm{P}_{2} \mathrm{Y}_{1}$ and $\mathrm{P}_{2} \mathrm{Y} 12$ are both GPCRs. P2Y1 couples to Gq and mediates platelet shape change and reversible aggregation. $\mathrm{P} 2 \mathrm{Y} 12$ couples to $\mathrm{Gi}$, resulting in intracellular $\mathrm{Ca}^{2+}$ mobilization via inhibition of adenylate cyclase. P2Y12 is the target for several common anti-platelet drugs, such as clopidogrel and ticagrelor [28]. 
P2X1

$\mathrm{P} 2 \mathrm{X} 1$ is an ATP-coupled ion channel permeable to $\mathrm{Ca}^{2+}$. Activation of the $\mathrm{P} 2 \mathrm{X} 1$ channel leads to the influx of $\mathrm{Ca}^{2+}$ across the plasma membrane, resulting in a transient shape change [28].

IP-receptor

The IP-receptor mediates platelet inhibition via binding of prostacyclin (PGI2). Binding of PGI2 results in activation of adenylate cyclase via Gs, leading to increased levels of cAMP and reduced $\mathrm{Ca}^{2+}$ mobilization, counteracting platelet activation [29].

\section{P-selectin}

P-selectin is not expressed on resting cells. Due to its location in a-granules, Pselectin becomes exposed on the platelet surface upon platelet activation. Pselectin binds to P-selectin glycoprotein ligand-1 (PSGL-1), present on leukocytes and endothelial cells, and mediates the recruitment of immune cells into a forming coagulum, and might participate in platelet adhesion to endothelial cells [30].

\section{Hemostasis}

Hemostasis has generally been divided into two parts, primary hemostasis involving vasoconstriction and the platelet response, and secondary hemostasis involving the actions of the coagulation system. This naming implies that primary hemostasis occurs first and is then followed by secondary hemostasis in a separate process. In reality, primary and secondary hemostasis are heavily intertwined and occurs simultaneously $[19,31,32]$. However, for simplicity, in the coming sections, each step will be explained separately.

\section{Primary hemostasis}

When a vessel is damaged, the endothelial cells lining the vessel will seize to secrete substances regulating the vessel tonus. Simultaneous activation of platelets lead to the release of vasoconstrictors. This reduces both the blood loss and the surface of the damaged area [29, 33-35]

Upon vessel damage, the extracellular matrix (ECM) becomes exposed. This contains platelet activating substances such as collagen, vWF, fibronectin, laminin and thrombospondin. If the shear rate of the damaged vessel is high, as in arteries, platelet adhesion is mediated through binding of vWF to GPIb-IX-V, whereas this interaction is not essential at lower shear rates, as in veins. Platelets in circulation bind to vWF, immobilized at the site of vessel damage. The GPIb-IX-V receptor complex has a fast on- and off-rate, allowing the platelet to roll along the vWF multimers. This slows down the platelets enough to allow adhesion, via $\alpha \operatorname{IIb} \beta_{3}$, and $\alpha 2 \beta 1$ [17-19], figure $1 \mathrm{~A}$. 

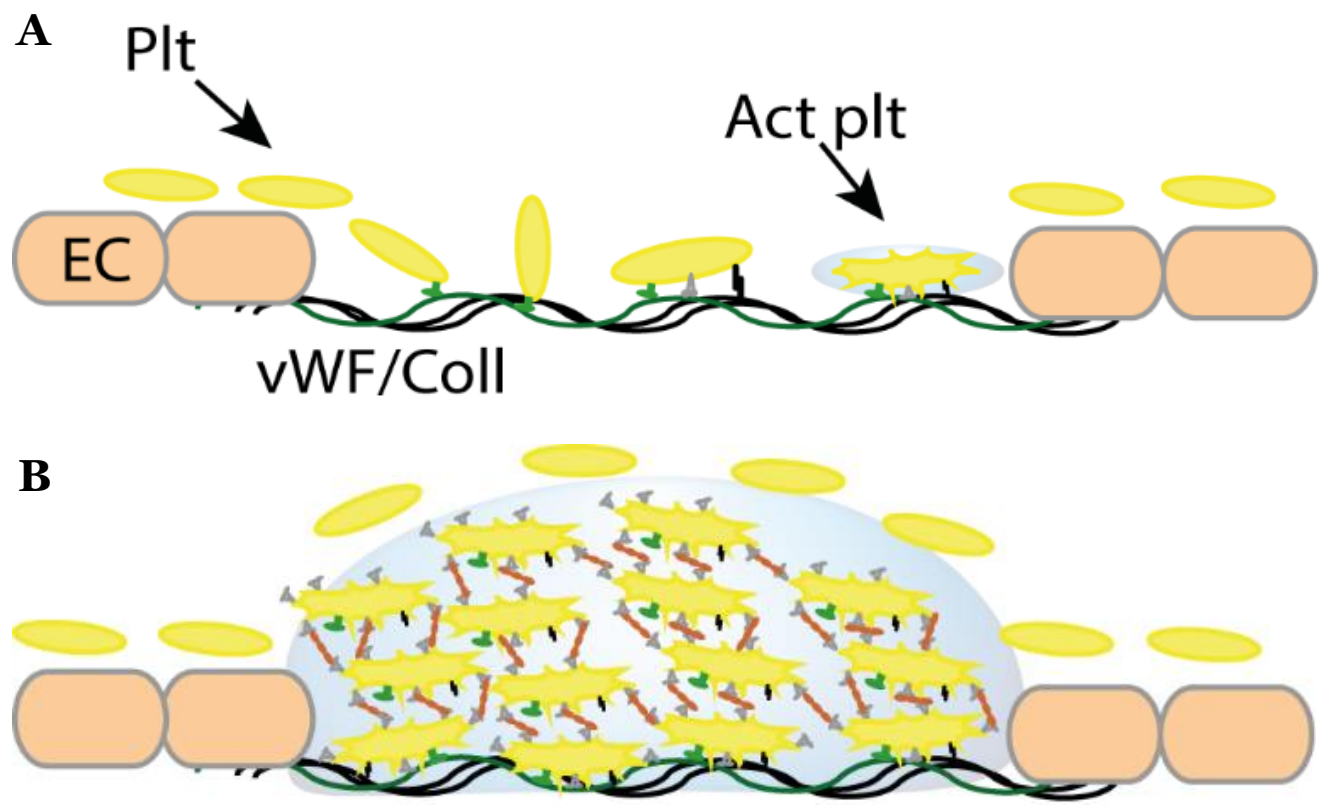

C
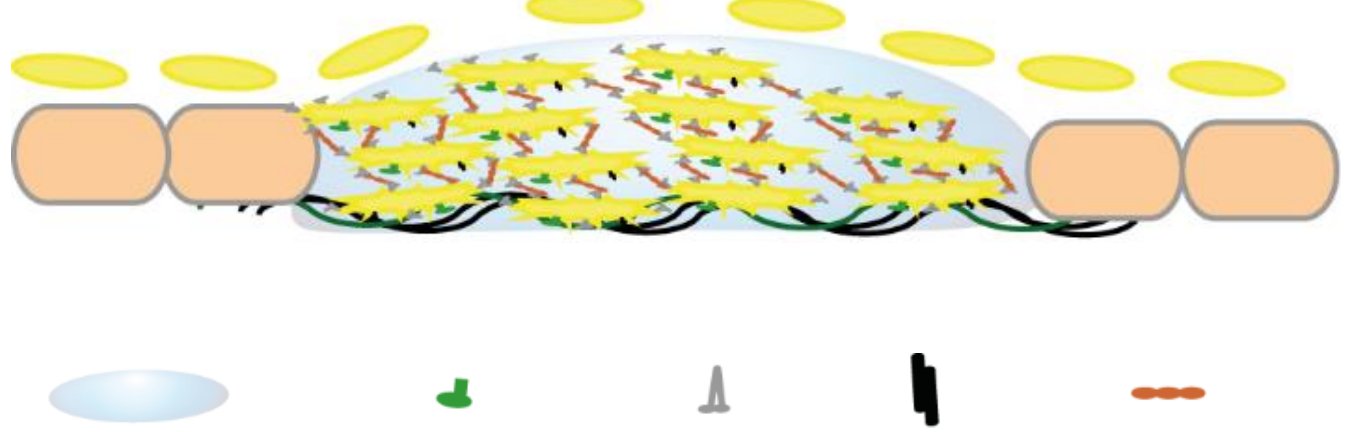

\section{ADP/TxA2 GPIb-IX-V allb 33 GPVI Fibrinogen}

Figure 1. Illustration of (A) platelet adhesion, (B) aggregation and (C) clot retraction. Endothelial cell (EC), activated (act), platelet (plt), von Willebrand factor (vWF), collagen (coll), thromboxane A2 (TxA2). 
The interaction of GPVI with collagen induces platelet activation, resulting in the release of ADP from dense granules and production of TxA2. These together with trace amounts of thrombin leads to reinforced platelet activation, and a shift in platelet integrins, primarily $\alpha \mathrm{IIb} \beta 3$ and $\alpha_{2} \beta 1$, into high affinity states, resulting in firm adhesion to the ECM $[18,22]$, figure $1 \mathrm{~A}$.

The release of ADP, TxA2 and formation of thrombin are also important for the recruitment of additional platelets to the site of damage. These platelets are tethered to the adherent platelets via $\alpha \operatorname{IIb} \beta 3$ binding to fibrinogen or vWF, and result in platelet aggregation and the formation of a platelet plug $[18,19]$, figure $1 \mathrm{~B}$.

Following aggregation, the platelets will constrict in an action called clot retraction. Clot retraction reduces the size of the platelet plug/clot and the vessel occlusion. Clot retraction is dependent on the interaction of $\alpha \operatorname{IIb} \beta 3$ with extracellular ligands, mainly fibrin(ogen), and anchoring to the cytoskeleton which mediates the constricting force and reduction in size [5, 11, 19], Figure $1 \mathrm{C}$. This constriction results in locally increased concentrations of soluble agonists such as thrombin due to reduced transportation rates of solutes within the clot [36, 37]. As the platelet plug builds up, the activation state of the peripheral platelets becomes limited as a consequence of reducing activating stimuli [36].

The formed platelet plug is not stable to the shear forces generated by the flowing blood. Hence the transformation of bound fibrinogen into a fibrin network is critical. This action is carried out by the coagulation system [19].

\section{Secondary hemostasis}

The coagulation system was described in 1964 as a cascade or a waterfall $[38,39]$. The classical description of two converging pathways of coagulation, the intrinsic pathway and the extrinsic pathway is based on these. The coagulation system consists of a number of coagulation factors that circulate in an inactive state and become activated upon a series of proteolytic cleavages, ending with the activation of thrombin and cleavage of fibrinogen into fibrin. As for primary and secondary hemostasis, the division into the intrinsic and extrinsic pathway is not as clear in vivo, with cross-talk between the two pathways [31, 34, 40], figure 2. Additional modifications have included the role of cell surfaces on which coagulation can take place, which greatly increases the speed of coagulation [41]. These models normally involve three phases of coagulation, the initiation phase, the amplification phase and the propagation phase [31, 34, 40], figure 3 . 


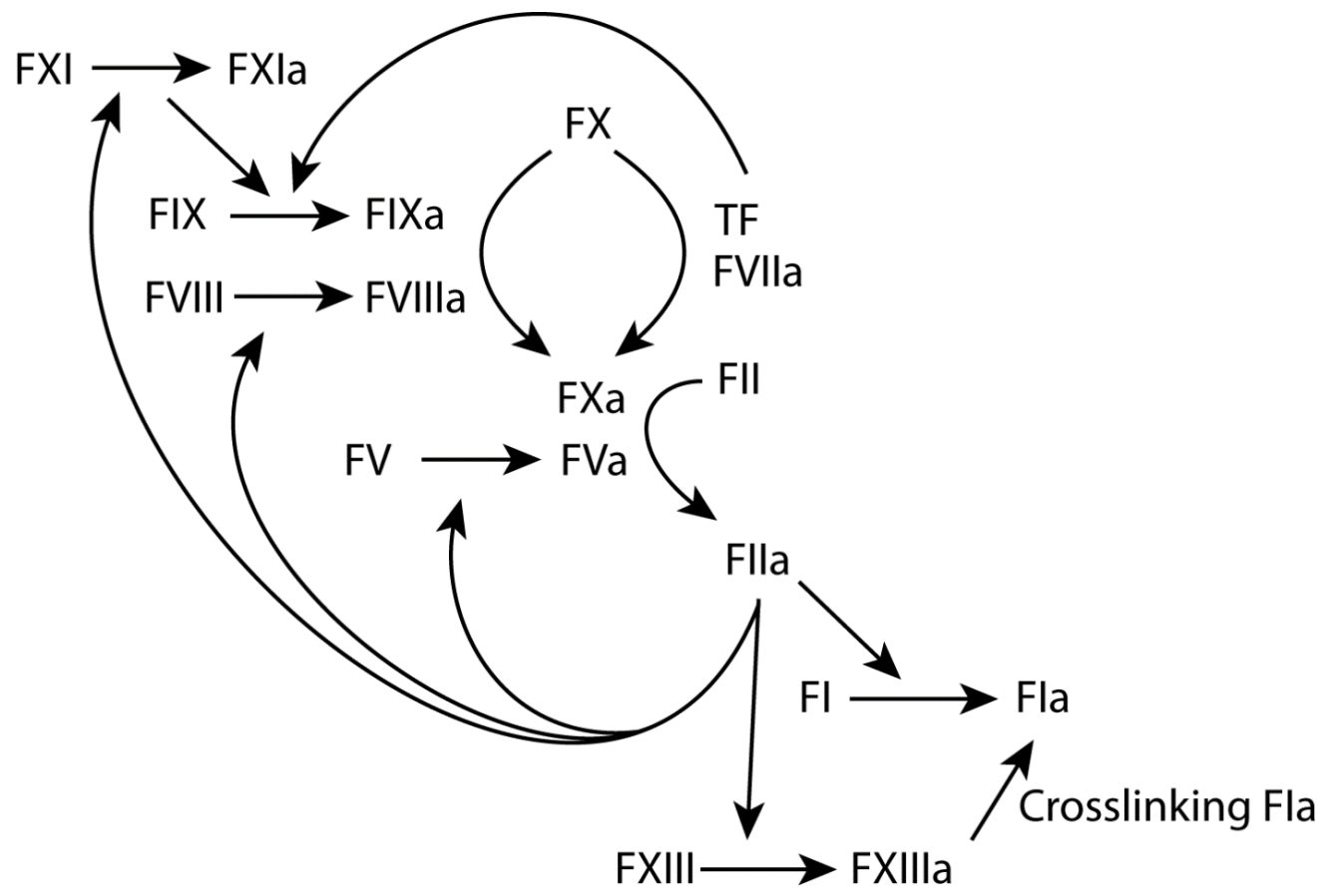

Figure 2. The coagulation cascade. Tissue factor (TF) thrombin (FII), fibrin(ogen) (FI).

Normally, tissue factor (TF) expressed outside the blood stream only becomes exposed upon vessel injury [40,42]. This TF located on a membrane surface forms the extrinsic tenase complex together with FVIIa and activates FIX $\rightarrow$ FIXa and $\mathrm{FX} \rightarrow \mathrm{FXa}$. FXa moves along the membrane surface and forms the prothrombinase complex together with FVa, and activate prothrombin (FII) to thrombin (FIIa). This initiation phase generates small amounts of thrombin, and is then inhibited by tissue factor pathway inhibitor (TFPI) [31, 40, 42].

The coagulation cascade then moves into the amplification phase, where the initially formed thrombin will activate platelets that have adhered to the site of injury. This leads to increased platelet activation, secretion and formation of a procoagulant platelet surface on which further coagulation can take place. Thrombin will activate FV $\rightarrow$ FVa, FXI $\rightarrow$ FXIa and FVIII $\rightarrow$ FVIIIa inducing its release from $\mathrm{vWF}$. As all coagulation factors have been activated, the coagulation cascade enters an amplification phase, primarily taking place on the procoagulant platelet surface. During the amplification phase, large amounts of thrombin are formed, via the formation of the intrinsic tenase complex, consisting of FVIIIa and FIXa. Additional FIXa is also generated by FXIa. The FXa formed will bind to the prothrombinase complex on the platelet surface, leading to further thrombin generation $[31,34,40]$, Figure 3. 


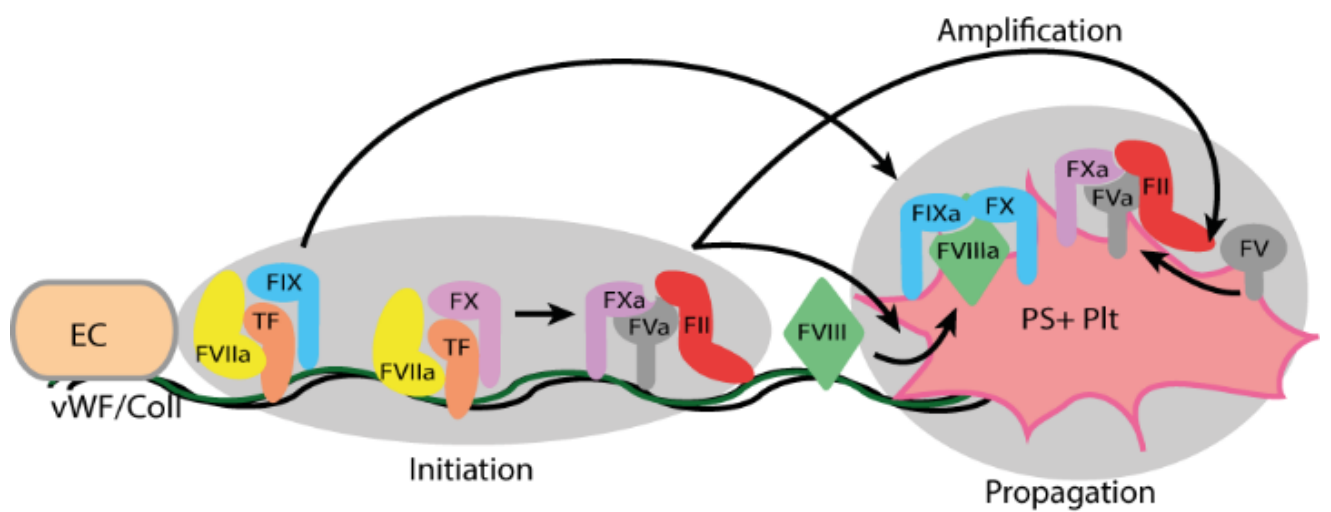

Figure 3. Illustration of the initiation of the coagulation cascade on the vessel wall, and propagation on a procoagulant platelet (PS+ plt). Endothelial cell (EC), von Willebrand factor (vWF), collagen (coll).

The thrombin formed during the propagation phase will first cleave fibrinogen into fibrin, resulting in the formation of a clot. The additional, and vast majority of the thrombin formed will cause additional platelet activation, activate FXIII $\rightarrow$ FXIIIa and thrombin activatable fibrinolysis inhibitor (TAFI). FXIIIa crosslinks the fibrin fibers, increasing the strength of the fibrin clot, whereas TAFI inhibits clot degradation, by plasmin, during fibrinolysis [31, 32, 43].

\section{Localization of hemostasis}

To avoid off-target clot formation and vessel occlusion, the hemostatic system must be localized to the site of vessel injury. There are several mechanisms in place to ensure this. Firstly, platelets and coagulation factors circulate mainly in an inactive state. The activation trigger, $\mathrm{TF}$, located outside the healthy vessel, only becomes exposed when the tissue is compromised [42]. Adhesion of platelets and initial activation of coagulation factors is thus directed to the site of injury. The subsequently formed platelet plug, covers the vessel damage and facilitates the containment of the hemostatic response by limiting diffusion away from the site of injury $[31,36,40]$.

In addition a quiescent platelet state away from the vessel damage is primarily achieved via endothelial cells, delimiting the site of injury. Healthy endothelial cells produce potent platelet inhibitors, such as PGI2 and nitric oxide (NO), which both function to inhibit platelet activation and reduce the activation state of escaped platelets. CD39, expressed by endothelial cells, counteract platelet activation by degrading extracellular ADP [29]. The healthy endothelium also expose heparinoids which repel the platelets, reducing the platelet-endothelial interaction. The heparinoids also function as anticoagulants that bind and enhance the activity of antithrombin, which in turn bind and inactivate thrombin, FXa, 
FXIa and to some extent also FIXa [29, 31]. Antithrombin inhibition is much more efficient when coagulation factors are in solution, while they are protected upon binding to cell surfaces or fibrin fibers $[31,40]$. Thrombomodulin expressed on the surface of endothelial cells will bind thrombin and induce the activation of Protein C, which together with Protein S, inactivate FVa and FVIIIa [29, 40]. These mechanisms function to limit both platelet activation and coagulation outside the site of vessel damage.

\section{Platelets and coagulation}

That platelets are heterogeneous has been known for a long time. The first observation of different platelet populations was described by Webber \& Firkin in 1965 [44]. They reported that platelets exposed to a hypotonic solution took on one of two different morphologies. One population spread without visible organelles and had breaks in the plasma membrane. The other was more contracted, had visible organelles and many pseudopodia. Further work describing different platelet subpopulations, their formation and functions have however mostly been performed during the last three decades.

\section{The plasma membrane}

The asymmetry of the platelet plasma membrane, where phosphatidylethanolamine and PS are located on the intracellular leaflet of the plasma membrane [10] is maintained by an aminophospholipid translocase (or flipase) that transports PS from the extracellular to the intracellular leaflet [45]. Activation of a scramblase $[46,47]$ and inactivation of the aminophospholipid translocase [48] upon platelet activation leads to the rapid exposure of PS on the extracellular leaflet [25, 49]. It was reported early, that different agonists varied in potency to induce exposure of PS [10, 25, 49-51]. PS exposure creates a surface for the assembly of coagulation factor complexes thus supporting the generation of thrombin, leading to a reduced clotting time. [49-51]. The procoagulant function of PS exposure was also shown to be blocked by binding of Annexin V, an anticoagulant protein which binds to PS [52-54].

Although other membranes exposing PS at the site of vessel damage, such as damaged endothelial cells, may also provide this surface [10], platelets are probably the most important source of PS $[31,55]$. The importance of PS exposure by procoagulant platelets is highlighted by the bleeding diathesis seen in patients with Scott syndrome. These patients have an impaired PS exposure in response to platelet activation [56].

\section{Description of the procoagulant platelet}

Since the late 1980's and onwards, it has been reported by several research groups that platelets differ in their exposure of PS, where some would bind Annexin V or 
an antibody against FV whereas others would not (early reports being [23, 57-6o]). Exposure of phosphatidylserine was also associated with the generation and shedding of platelet microparticles [57-66]. It has been suggested by some that the platelet microparticles harbor much of the procoagulant surface [61]. Others have shown a moderate role for microparticles in thrombin generation [23]. As discussed further below, there is reason to believe that the particles described as microparticles in older studies may rather correspond to smaller platelets $[67,68]$.

In 1997, Heemskerk et al reported that adherent platelets would display two distinct morphologies [59]. On fibrinogen, they would gradually spread on the surface without a marked increase in intracellular $\mathrm{Ca}^{2+}$. On collagen, however, a substantial fraction of platelets would instead spread slightly, followed by swelling into a balloon-like structure and gradually detach from the surface. This was associated with exposure of PS and the release of microparticles from the platelet balloon. Adhesion to collagen resulted in increased intracellular $\mathrm{Ca}^{2+}$ in approximately $60 \%$ of the platelets and corresponded to binding of Annexin V. Subsequent addition of thrombin increased this to $80 \%$. Similar morphologies has since been described and elaborated on in other studies [63-65, 69, 70]. In 2015 it was reported by Agbani et al [65] that platelets may take on different morphologies. Some platelets would spread markedly on the surface after which a ballooning protrusion would appear and PS exposure could be detected.

Coated platelets, a type of procoagulant platelets, have primarily been studied in suspension. They were first defined as a platelet subpopulation with a high binding of FV, which would form upon stimulation with the GPVI agonist convulxin and thrombin [23]. The high FV binding was shown to be functional as it was associated with an increased binding of FXa and higher thrombin generation. Further, binding of FV and Annexin V overlapped upon stimulation with thrombin and convulxin. It was later reported that coated platelets also bound other $\alpha$-granule proteins; fibrinogen, vWF, thrombospondin, fibronectin and a2-antiplasmin [71, 72].

Whereas the coated platelets were found to have an increased binding of fibrinogen and other a-granule proteins [71], several studies have shown that PS-exposing platelets have a reduced binding of PAC-1 [64, 70, 71, 73, 74], a monoclonal antibody that recognizes the active conformation of $\alpha \operatorname{IIb} \beta 3$ [75]. In procoagulant platelets, a transient PAC-1 binding, which is secondarily downregulated at the time of Annexin V binding or SCIP formation (see below) has been reported [64, $70,73]$. In 2002, Dale et al reported that coated platelets showed a low binding of PAC-1 but retained a high binding of $\alpha \mathrm{IIb} \beta 3$ ligands such as fibrinogen [71] and this has since been repeated by others $[74,76]$. The procoagulant ballooning platelets described by Agbani et al bound fibrinogen on the spread platelet body but not on the balloon-structure [65].

The binding of $\alpha$-granule proteins to coated platelets are, as reported by Dale et al [71], retained through covalent linking via serotonin and dependent on transglutaminase activity. It was hypothesized that the derivatization of the $\alpha-$ 
granule proteins led to a stronger binding of the new larger molecule to the platelet surface, as the binding sites on each of the molecules would also be linked [72]. The transglutaminases tissue transglutaminase and FXIII are both present in platelets and have been suggested as candidates [71]. FXIII was reported to be important in the downregulation of $\alpha \operatorname{IIb} \beta 3$ in the formation of procoagulant platelets, as this was reduced in a patient with FXIII deficiency. In this study, extracellular FXIII seemed to be especially important, perhaps via direct binding to $\alpha \operatorname{IIb} \beta 3$ [70]. Mattheij et al present a combined role for $\alpha \mathrm{IIb} \beta 3$ and FXIII in the formation and orientation of the formed fibrin network [77]. Abaeva et al also show a decrease in fibrinogen binding to PS exposing platelets in a patient with FXIII deficiency, but interpret this as a non-significant reduction [74], whereas FXIII knockout in mice caused no reduction in the generation of coated platelets [76, 77].

The concept of the coat model was elaborated on by Abaeva et al [74], who suggested that the described coat was rather a cap. They showed that fibrinogen and thrombospondin surface binding was located in a cap on the platelet, rather than being spread over the entire platelet surface as the name coated would imply. This cap was located at the site of platelet adhesion to the surface or platelet aggregate, and thus implies a functional role for the cap structure. The "limited" importance of FXIII, as well as previous studies implicating a role for thrombin in the binding of fibrinogen [78], generated a new hypothesis. Abaeva et al suggested a role for thrombin in the formation of the cap structure, where the polymerization of fibrin would be important for the retention of fibrin(ogen) and thrombospondin. This hypothesis was strengthened by the fact that stimulation with thrombin and collagen-related peptide (CRP) in the presence of GPRP (a peptide inhibiting fibrin polymerization) $[79,80]$ reduced fibrin(ogen) binding whereas ancistron (which is claimed to induce fibrin polymerization) would increase the fibrin(ogen) binding also in the absence of thrombin [74]. Mattheji et al describe that on Annexin V binding platelets, FXIII is spread out over the entire platelet [77]. However, judging from the presented images, the localization of FXIII resembles the cap structure described by Abaeva et al [74]. Taken together, the morphology described by Abaeva, Mattheij and Agbani et al all resemble each other, as well as previous descriptions by Heemskerk et al and Kulkarni \& Jackson, and are likely varying descriptions of the same phenomenon $[59,65,70,74,77]$.

As a consequence of the reduced function of $\alpha \mathrm{IIb} \beta 3$ and a swollen morphology [59], procoagulant platelets have a reduced ability to form platelet-platelet connections [64, 70,73,74], and have reduced adhesive strength [59, 81], which probably explain their location in distinct patches and on the edges of growing aggregates $[64,74]$.

\section{Procoagulant platelets and agonists}

Early on, it was shown that platelet agonists differed in their ability to induce PS exposure. The $\mathrm{Ca}^{2+}$ ionophores A23187 and ionomycin have been found to be the most potent in this regard $[25,50,52,57,61,63]$. Similar potencies have also been 
found for other agents yielding an increase in intracellular $\mathrm{Ca}^{2+}$, such as thapsigargin [58] and the complement complex $\mathrm{C}_{5} \mathrm{~b}-9$ [60]. Among the more physiological agonists, a combination of a GPVI agonists such as collagen or convulxin along with one or more agonists towards the thrombin receptors PAR1 and -4 have been shown by many to be the most potent [23-25, 50-52, 57, 59, 61]. In adhering platelets, GPVI agonists alone have been shown to be potent inducers of PS exposure, although this can be further increased by the presence of additional agonists $[59,69,70]$. Agonists towards the immune receptor $\mathrm{Fc} \gamma \mathrm{R}$ have also been shown to induce PS exposure as Fc $\gamma \mathrm{R}$ forms a complex with GPVI [19, 21, 82]. In FcyR knockout mice, GPVI-agonists were unable to induce the formation of procoagulant platelets [76].

\section{Procoagulant platelets and calcium}

As mentioned above, the increase in intracellular $\mathrm{Ca}^{2+}$ is essential for the formation of procoagulant platelets $[58,59,63,70]$. This was further highlighted by the procoagulant platelets described by Kulkarni and Jackson, denominated sustained calcium-induced platelet morphology (SCIP) [70]. This $\mathrm{Ca}^{2+}$ may be mobilized from different sources. Upon platelet activation, most agonists result in release of $\mathrm{Ca}^{2+}$ from intracellular stores in the DTS, dense granules and lysosomes. Other stores from which $\mathrm{Ca}^{2+}$ may be mobilized include the mitochondria and influx of extracellular $\mathrm{Ca}^{2+}[83,84]$.

Mobilization of extracellular $\mathrm{Ca}^{2+}$ has been shown to be crucial, as a reduction in extracellular $\mathrm{Ca}^{2+}$ leads to a severe reduction in the formation of procoagulant platelets [57-59, 62, 63, 70]. Extracellular $\mathrm{Ca}^{2+}$ may enter the cell through activated receptor- or second messenger-operated channels. These include the ATP P2X1 channel and the transient receptor potential canonical (TRPC) channels thought to be activated by diacylglycerol (DAG). Another mechanism of entry is storeoperated calcium entry (SOCE). Depletion of intracellular $\mathrm{Ca}^{2+}$ stores stimulates the formation of a $\mathrm{Ca}^{2+}$-channel consisting of the plasma membrane channel Orai1 and the $\mathrm{Ca}^{2+}$ sensor STIM1 located in the membrane of the DTS [84]. Depletion of STIM1 or Orai1 in mice was shown to completely block SOCE, and led to a reduced but not abolished platelet PS exposure in response to GPVI stimulation. However, in response to dual stimulation with convulxin and thrombin, only a slight reduction in PS exposure was observed, indicating multiple pathways for $\mathrm{Ca}^{2+}$ entry [85]. Harper et al showed that this additional pathway may be mediated by the channels TRPC3 and 6. Opening of the TRPC channels lead primarily to an influx of sodium $\left(\mathrm{Na}^{+}\right)$, which may cause indirect $\mathrm{Ca}^{2+}$ influx via the reverse action of the $\mathrm{Na}^{+} / \mathrm{Ca}^{2+}$-exchanger [86].

A reduced mitochondrial potential has been observed in procoagulant platelets $[87,88]$. Inhibition of the mitochondrial permeability transition pore (mPTP) in response to convulxin and thrombin was shown to reduce most of the features of coated platelets; Annexin V binding, fibrinogen binding, reduced PAC-1 binding, thrombin generation and clot retraction in human [87], and mouse platelets [73, 
88]. It has been reported that the MPTP may form in response to an increased intracellular $\mathrm{Ca}^{2+}$. The intracellular $\mathrm{Ca}^{2+}$ is taken up by the mitochondria via the mitochondrial calcium uniporter. The increasing mitochondrial $\mathrm{Ca}^{2+}$ level eventually lead to the opening of the MPTP [89-91]. Whether the opening of the mPTP results in the release of additional $\mathrm{Ca}^{2+}$ which induces a procoagulant response, or whether the mPTP has another mechanism of action is currently unknown [90]. The lack of impact of mPTP inhibition seen upon platelet stimulation with the $\mathrm{Ca}^{2+}$-ionophore $\mathrm{A} 23187$ [87, 88] suggests that the intracellular $\mathrm{Ca}^{2+}$ concentration is the important trigger. However, contradicting this, one study report that the measured intracellular $\mathrm{Ca}^{2+}$ was similar in A23187 and thrombin+convulxin stimulated platelets, where mPTP formation is important for a procoagulant response [89]. In addition, the association to PS exposure was stronger for mitochondrial $\mathrm{Ca}^{2+}$ and opening of the MPTP than for intracellular $\mathrm{Ca}^{2+}$. These inconsistencies might be the result of multiple pathways leading to procoagulant transformation, where the mitochondria are important in some pathways but not others [46].

Many of the procoagulant features can be attributed to the increased intracellular $\mathrm{Ca}^{2+}$ concentration. The increased $\mathrm{Ca}^{2+}$ will for instance lead to the activation of calpain, which has been shown to be important for the procoagulant phenotype $[57,62,63,70,73,81,92-94]$. Calpain cleaves many proteins, among which the cytoskeletal proteins talin, filamin and myosin are found, as well as $\alpha \operatorname{IIb} \beta 3$ [57, 73, $81,94,95]$. Cleavage by calpain leads to $\alpha I I b \beta 3$ inactivation and a reduced PAC-1 binding $[70,73,94]$. This inactivation may result from cleavage of the integrin itself [73] or from uncoupling of the integrin from the cytoskeleton [81, 83]. Calpain activity is associated with the formation of microparticles [57, 61-63, 69, 93] and the swollen/ballooning morphology [63], which are likely caused by reduced connections between the plasma membrane and the cytoskeleton. The dissociation of $\alpha \operatorname{IIb} \beta_{3}$ from the cytoskeleton has also been suggested to be the reason why procoagulant platelets do not participate in clot retraction [83], which is mainly dependent on $\alpha \operatorname{IIb} \beta 3[2,5,11,37,96]$. Calpain may however not be the sole protein responsible for the procoagulant morphology or $\alpha \mathrm{IIb} \beta 3$ inactivation. A role has been described for TMEM16F $[73,97,98]$ and FXIII as mentioned above [70].

Phospholipid asymmetry is maintained in an ATP-dependent manner by aminophosholipid translocase [45], which becomes inactivated in procoagulant platelets [48]. In addition, a scramblase thought to be TMEM16F [47] (also called anoctamin-6) is activated in a $\mathrm{Ca}^{2+}$ dependent manner and is involved in the rapid PS exposure seen upon an increase in intracellular $\mathrm{Ca}^{2+}[46,47,98]$.

The swollen balloon morphology observed by Agbani et al was associated with a disruption of the cytoskeleton at the site of the balloon-protrusion. In addition, ballooning was shown to be dependent on the entry of chloride ( $\mathrm{Cl}-$ ) and $\mathrm{Na}^{+}$and the consequent fluid entry this causes. Whereas other members of the TMEM16 family are $\mathrm{Ca}^{2+}$-activated $\mathrm{Cl}^{-}$-channels, TMEM16F is permeable $\mathrm{Ca}^{2+}$ and $\mathrm{Na}^{+}$, and to $\mathrm{Cl}^{-}$at high intracellular $\mathrm{Ca}^{2+}$, and may thus be responsible for the $\mathrm{Cl}^{-}$or $\mathrm{Na}^{+}$entry 
$[99,100]$. This again highlights the importance of an increased intracellular $\mathrm{Ca}^{2+}$ in the formation of procoagulant platelets. Platelet ballooning is likely a result of osmotic swelling orchestrated through the activation of ion channels and disruption of the cytoskeleton, which would otherwise withstand the increased osmotic pressure. As TMEM16F dysfunction is thought to be responsible for the Scott syndrome [47] this links the formation of ballooning procoagulant platelets with the bleeding phenotype seen in Scott syndrome patients.

\section{Platelet age}

Platelets have a life span of around 10 days in circulation $[3,6]$. The newly formed platelets contain mRNA derived from the megakaryocyte. The mRNA is quickly degraded during circulation, hence it will only be detected in newly formed platelets $[6,101,102]$. The presence of mRNA is utilized to determine the immature platelet fraction, also called reticulated platelets, using dyes such as thiazole orange (TO) [6, 101-103]. It has been reported that young platelets are more reactive than older platelets $[104,105]$, thus may also be more prone to expose PS. The literature is however in disagreement on the matter. One study reported PS exposure in $73 \%$ of $\mathrm{TO}+$ platelets compared to $24 \%$ in TO- platelets [23]. Another reported that PS exposure was higher in both resting and activated $\mathrm{TO}+$ platelets and that the increase in PS exposure in response to stimulation was larger in $\mathrm{TO}+$ platelets [106]. On the other hand, a recent study opposes this. They did not find any difference in PS exposure between young ( $<24$ hours) and older platelets [107]. This study did however confirm that PS exposure was higher in $\mathrm{TO}+$ platelets than TO- platelets, but report that TO labelled large platelets, rather than young platelets.

\section{Platelet concentrates}

Platelet concentrates can be produced from whole blood after the donation has been completed. These are called platelet-rich-plasma (PRP) or buffy-coat (BC) platelet concentrates, and contains platelets pooled from 3-6 donors. Apheresis platelets are instead separated from the blood during collection, hence the other blood components can be returned to the donor. This allows for more platelets to be collected, yielding one or more platelet units from each donor without the need of pooling platelets from several donors [108-110].

Platelet concentrates are transfused to prevent bleeding, primarily in thrombocytopenic patients. This can be done therapeutically in patients with active bleeding or prophylactically to prevent bleeding in patients with an increased risk of bleeding, such as patients with hematological or oncological malignancies [111-113]. Platelet transfusions are however not risk-free, (reviewed in $[108,110,112-114])$. Due to the short shelf-life of platelet concentrates, up to 7 days $[110,113,115]$, the availability of platelet concentrates may at times be scarce 
$[110,112]$. Therefore, it is important to limit the number of platelet transfusions when possible [112]. An increased transfusion efficiency may also reduce the number of transfusions needed [116].

Transfusion efficiency of platelet concentrates is generally evaluated using different expressions of the post transfusion increase in platelet count, such as the corrected count increment [113], although clinical assessment of patient bleeding is the ideal measurement $[113,117]$. These in vivo measurements are often inconvenient and may be difficult to interpret in heterogeneous patient populations [117-119]. Thus, in clinical routine and in research studies, different in vitro parameters, some of which are described below, are used routinely to determine the quality of the platelet concentrates [118-122]. Due to the difficulties in determining transfusion efficacy, few of the in vitro parameters have been correlated to in vivo transfusion outcome $[119,121,122]$.

The function of platelets is best maintained if platelet concentrates are stored at room temperature $\left(20-24^{\circ} \mathrm{C}\right)[123,124]$. However, this storage temperature increases the risk of bacterial growth in the concentrates and is the main factor limiting the storage time today $[110,116]$. During storage, the platelet function will also deteriorate in a process called the platelet storage lesion (PSL) $[110,115,116$, $120,125]$. The transfusion efficacy, determined as corrected count increment, has been shown to decrease with increasing storage time [115]. But this has not been correlated to an increased bleeding in patients [126, 127]. As strategies for pathogen reduction are being developed, the risk of bacterial growth can be reduced rendering the quality of the platelet concentrates the limiting factor for storage time instead $[116,122]$. Therefore, the need for quality assessment and strategies for maintaining the quality of platelet concentrates may increase [122].

Blood gases and metabolic parameters such as $\mathrm{pO} 2, \mathrm{pCO} 2, \mathrm{pH}$, glucose and lactate are often measured routinely in platelet concentrates $[110,119,120,125]$, although $\mathrm{pH}$ may be the only required parameter $[110,119]$. If the $\mathrm{pO} 2-\mathrm{pCO} 2$ balance is disturbed or glucose is depleted, the $\mathrm{pH}$ of the platelet concentrate may drop. A drop in $\mathrm{pH}$ below 6.0 has been associated with reduced platelet viability [110, 119, 124, 128].

Swirling is routinely used to assess the morphology of platelets [110, 119, 125]. Platelets with a discoid shape exposed to a light source will reflect light (shimmer), which can be detected by the naked eye. Reduced swirling was associated with a pH below 6.4 or above 7.6 [129], which has been correlated to a reduced platelet viability of transfused platelets [124, 128].

It has been argued that the parameters mentioned above may be too insensitive and only reflect severe platelet dysfunction [120,122]. Hence researchers have also used other in vitro parameters some of which are more closely related to platelet function. These include flow cytometric evaluation of platelet concentrates.

Since the collection procedure and storage may cause platelet activation, the "spontaneous" exposure of GPIb and activation markers P-selectin, active 
conformation of $\alpha \mathrm{IIb} \beta 3, \mathrm{CD} 63$ or PS have often been determined [119]. A reduction in GPIb expression has been correlated to a reduced in vivo viability [130]. An increased exposure of P-selectin has produced variable results, where some studies found an inverse correlation to in vivo platelet recovery $[131,132]$ and survival [132]. Others report that, as P-selectin is rapidly shed in vivo, it does not affect platelet recovery [133] or survival [134]. Platelet activation and the corresponding P-selectin exposure may therefore only be correlated to transfusion outcome under certain circumstances [110]. In addition, the agonist induced exposure of platelet activation markers may also be used to determine the platelet activation potential and may be more informative of platelet function, but this has yet to be established $[119,120]$. The platelet activation response measured in this way, is generally reduced with storage time [110, 119, 120, 125]. In Paper II, we discuss the use of the lysosomal marker LAMP-1, and formation of platelet subpopulations as possible additional markers of the platelet activation potential. 


\section{Methods}

\section{Anticoagulation}

There is no consensus on the best anticoagulant to use for platelet studies [135]. Throughout the thesis we have used citrate, acid citrate dextrose (ACD), heparin and hirudin as anticoagulants. As different anticoagulants have different effects on the collected blood sample [136-138], it is important to know the function of the anticoagulant used.

Citrate is the standard anticoagulant used for routine coagulations tests, as well as the most common anticoagulant used in platelet research. It is normally added to blood at a ratio of 1:9 and will therefore cause some sample dilution. Citrate is a $\mathrm{Ca}^{2+}$-chelator acting by reducing the extracellular calcium concentration and thereby inhibiting thrombin generation $[136,138]$. It is well known that citrate increases the potency of ADP stimulation compared to other anticoagulants [136, 137, 139]. The citrate anticoagulant effect can be reversed by re-calcification of the sample [139], although a difference in the platelet response may persist [138]. In situations where thrombin is to be used as the platelet agonist, citrate may however be the only viable option. Due to this, citrate was used as anticoagulant in Paper I, III and IV.

$\mathrm{ACD}$ is a citrate based anticoagulant also causing a reduction in $\mathrm{pH}$. As for citrate, it causes sample dilution. ACD is primarily used for isolation of platelets, as the low $\mathrm{pH}$ helps to keep the platelets quiescent during preparation. The apheresis platelets used in Paper II were anticoagulated in an ACD solution.

Heparin is a powder anticoagulant, spray-coated on the inside of blood collection tubes, and therefore do not dilute the collected blood sample. Heparin is an indirect thrombin inhibitor and it functions by catalyzing the inactivation of thrombin by antithrombin [33, 34]. Heparin was used as the anticoagulant in blood obtained from the blood donation central, and locally obtained blood, in Paper I. Heparinized blood was used for platelet stimulation with agonists other than thrombin, and with thrombin stimulation in isolated platelet samples. Heparin may enhance the effect of ADP stimulation, although to lesser extent than citrate $[136,137]$.

Hirudin prevents sample coagulation by directly inhibiting thrombin. It is a spraycoated anticoagulant, hence does not cause sample dilution. Hirudin is the

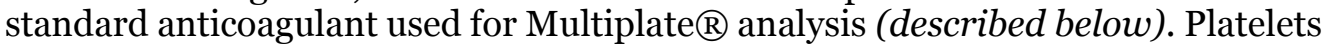
in hirudin whole blood has been reported to be sensitive to aggregation in response to ATP, via the conversion of ATP to ADP [140]. In addition, it was recently found that platelets in hirudin form platelet microaggregates during "storage", resulting in a reduction in platelet count and reduced Multiplate $\mathbb{R}$ responses with time [141]. Hence the authors recommend that the Multiplate ${ }^{\circledR}$ analysis of hirudinized 
blood is performed within 2 hours, as compared to 3 hours recommended in the manufacturer instructions.

EDTA is a calcium chelator and the standard anticoagulant used for blood cell counting. EDTA is inappropriate for platelet research as it will lead to irreversible inactivation of the fibrinogen receptor $\alpha \operatorname{IIb} \beta 3[135,137]$. EDTA has been used systematically for cell counting in Paper IV, and when possible, throughout the thesis.

\section{Agonists}

Platelets can be activated with different agonists. Agonists employed in this thesis work are cross-linked collagen-related peptide (CRP-XL) [142] and convulxin, which are both GPVI agonists. The thrombin receptors PAR1 and PAR4 were stimulated with the use of thrombin, PAR1-activating peptide (AP) or PAR4-AP. PAR1-AP and PAR4-AP are short peptides which correspond to the receptor Nterminal following cleavage by thrombin. The amino acid sequences used were SFLLRN for PAR-1 [143] and AYPGKF for PAR4-AP [144]. ADP, stimulating P2Y1 and P2Y12 was used as agonist in Paper I. As ADP is released by activated platelets, ADP will be present in all activated samples and participate in the platelet response, unless ADP-activation is specifically inhibited.

\section{Light transmission aggregometry}

Light transmission aggregometry (LTA) was originally described by Born and O'Brien in 1962 [145, 146]. LTA is considered the gold standard for evaluation of potential platelet function defects, but also suffers from a lack of standardization. Due to its open configuration, it is also a commonly used research tool $\left[135,147^{-}\right.$ 149].

LTA is based on the principle that light transmission through a platelet sample increases as the platelets aggregate. LTA is normally performed at $37^{\circ} \mathrm{C}$ under constant stirring. LTA can be performed in PRP or a suspension of isolated platelets. The limits of aggregation are measured as the light transmission through a non-aggregated platelet sample, which is set to o\% light transmission/ aggregation. The maximal signal is determined by measuring the light transmission through a background sample, platelet poor plasma (PPP) or buffer, if isolated platelets are used, and this is set to $100 \%$ light transmission/aggregation $[135,147,150]$.

When an agonist is added to the platelet sample, platelet shape change is the first response that may be noted. Due to an increase in platelet size, a small decrease in light transmission is seen, before aggregation and a consequent drop in light transmission ensues, figure 4. Quantification of the aggregation response can be performed using different parameters. The most commonly used parameter is 
maximum aggregation [147, 150]. In Paper IV, beside maximum aggregation, we also evaluated the time to maximum aggregation. Figure 4 shows a typical aggregation curve with parameters indicated. In cases where weaker agonists are used, aggregation may be reversible. In these situations, the occurrence and/or extent of reversible aggregation may also be informative [150]. In Paper IV, platelet stimulation was strong, hence no reversible aggregation was observed.

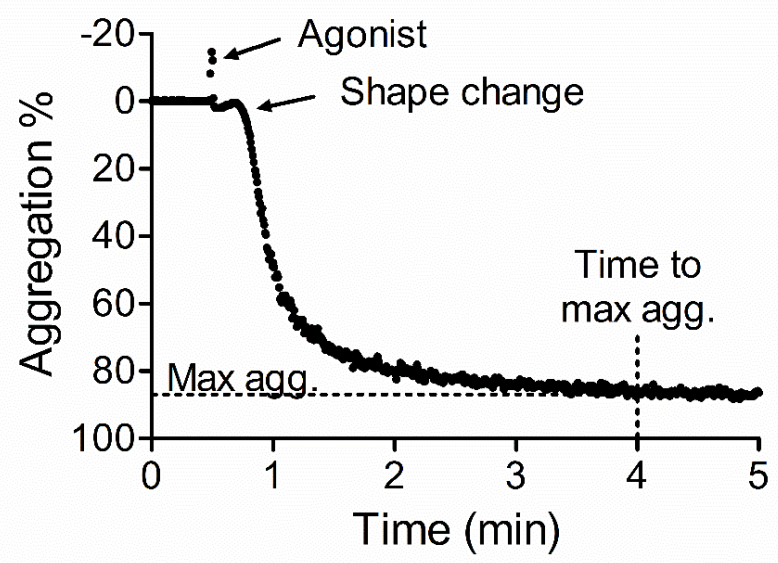

Figure 4. A typical trace from a light transmission aggregometry (LTA) experiment. Different features of the curve, as well as evaluated parameters are indicated.

\section{Multiplate $₫$}

Whole blood aggregometry may be analyzed using the Multiplate ${ }^{\circledR}$ platform. In this assay, aggregometry is measured as the change in resistance that occurs as platelets adhere and aggregate between two electrodes. Measurements in whole blood has the additional advantage of the presence of other blood cells, which brings the assay closer to physiological conditions and also eliminates the need for prior sample preparation $[147,149,151]$. The time frame and simplicity of use makes it suitable as a point-of-care instrument [147]. Aggregation using Multiplate $\AA$ is measured during 6 minutes and reports area under the curve (AUC) as the standard parameter [151]. Additional parameters given are maximum aggregation and rate of aggregation. 


\section{Calibrated automated thrombogram}

The generation of thrombin in a sample can be measured using calibrated automated thrombogram (CAT). In Paper IV, we measured the generation of thrombin in a PRP sample after 10 min agonist stimulation. Initiation of the coagulation cascade, and thus thrombin generation, requires a trigger, $\mathrm{Ca}^{2+}$ and a phospholipid surface. In Paper IV, tissue factor was used as the trigger whereas the phospholipid surface was provided by the platelets in the sample. CAT measurements are initiated by the addition of a fluorescent thrombin substrate and sufficient amounts of $\mathrm{Ca}^{2+}$. Thrombin generation is then measured as the cleavage of the fluorescent substrate and determined as the increase in fluorescence. With the use of a calibration curve, the software will automatically correct for different parameters, such as substrate consumption and inner filter effect. Thrombin generation is plotted (normally as the mean of triplicate samples) as a function of time and can be quantified with a set of parameters derived from it [152-154]. Examples of thrombin generation curves are shown in figure 5.
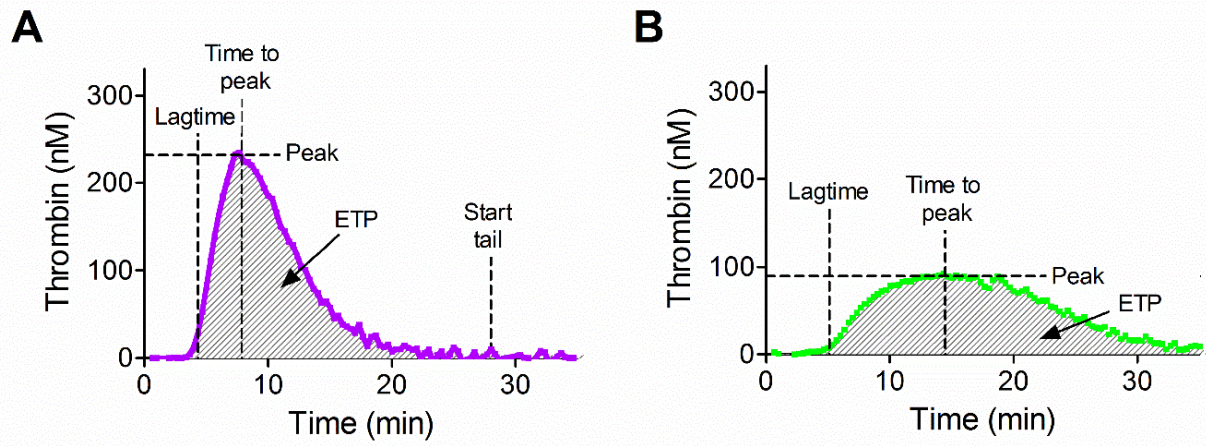

Figure 5. Thrombin generation curves, indicating the different parameters. Samples activated with (A) $C P R-X L+P A R 1-A P+P A R 4-A P$ or (B) PAR4-AP. Endogenous thrombin potential (ETP).

The generation of thrombin is initially slow, and normally undetectable. When thrombin has been generated in sufficient amounts, the coagulation cascade feedback and feedforward systems are engaged and initiate the propagation phase of thrombin generation. The time until thrombin propagation occurs is called the lagtime. This correlates to the formation of a clot seen in clotting assays like PT and APTT. Thrombin is then generated quickly, reaching a maximum, before diminishing and returning to baseline. The maximum thrombin concentration is denominated peak thrombin, and the time required to reach this is called time to peak. The time at which the curve returns to baseline, start tail, is mainly used by the program to set the limits of the curve. The total thrombin generated from start of the propagation phase until the return to baseline is called endogenous 
thrombin potential (ETP). These parameters may vary independent of each other [152-154], figure 5 shows two curves with different kinetics, but a similar ETP.

\section{Free oscillation rheometry}

Free oscillation rheometry (FOR) can be used to measure the viscosity and elasticity of a sample. It can be used for samples of whole blood, PRP and plasma $[96,155]$. FOR was performed in Paper IV, for measurements of viscosity and elasticity in whole blood samples, using the ReoRox G2 instrument (MediRox AB, Nyköping, Sweden).

In FOR, a sample is added to a sample cup (12 $\mathrm{mm}$ in diameter; figure 6A). The sample cup is rotated $4^{\circ}$ and released which sets the cup in free oscillation along the longitudinal axis, with a frequency of $10 \mathrm{~Hz}$. This is repeated every $2.5 \mathrm{~s}$. The amplitude and duration of the cup oscillation is measured optically and presented as the damping and frequency of the oscillation, respectively. From these measurements, the different instrument parameters can be calculated [156]. When the sample viscosity is low (as in a fluid sample), the damping is also low and the oscillation frequency is high. This is because only a small part of the sample, close to the cup wall, is affected by the rotation of the sample cup, and will reduce the oscillation [155-157]. As the samples begins to coagulate, a larger part of the sample will be affected by the oscillation and increase the damping, while the frequency is reduced. As the clotting increases further, the damping will again be reduced. After full sample clotting has occurred, the damping curve is no longer reliable [155]. Typical curves for damping and frequency are shown in figure 6B. The sample clotting time is given by the parameter COT1 and reflects the time point when the sample dampening (D) and oscillation frequency $(\mathrm{Fq})$ reach a preset value $\sqrt{ }\left(\Delta F q^{2}+\Delta D^{2} \geq C\right)[156]$. The COT1 parameter is very well correlated to the clotting time given by the gold standard method of visual inspection of a tilting tube $[156,158]$.

Once the sample has clotted and the fibrin strands have formed, it is possible to measure the clot elasticity. Elasticity is measured using a sample cup with a cylindrical bob (6 $\mathrm{mm}$ in diameter) immersed in the center of the sample cup, Figure 6A. Fibrin strands that form between the sample cup and the bob will contribute to the clot elasticity. In cases where whole blood or PRP samples including platelets are used, these parameters also include the clot retraction exerted by platelets $[96,158]$. In fact, in the presence of sufficient amounts of platelets, the maximum elasticity mainly reflects the platelet dependent clot retraction [96]. In situations where platelets are present, the contractile forces are stronger and it is therefore beneficial to use a sample cup and bob with gold coated surfaces. Gold-coating increases the attachment strength of fibrinogen and reduces the risk of clot detachment [158]. The parameter COT2 denotes the onset of clot elasticity measurements which begins once the sample clotting is complete [159]. Clot elasticity is also calculated from the frequency and damping parameters 

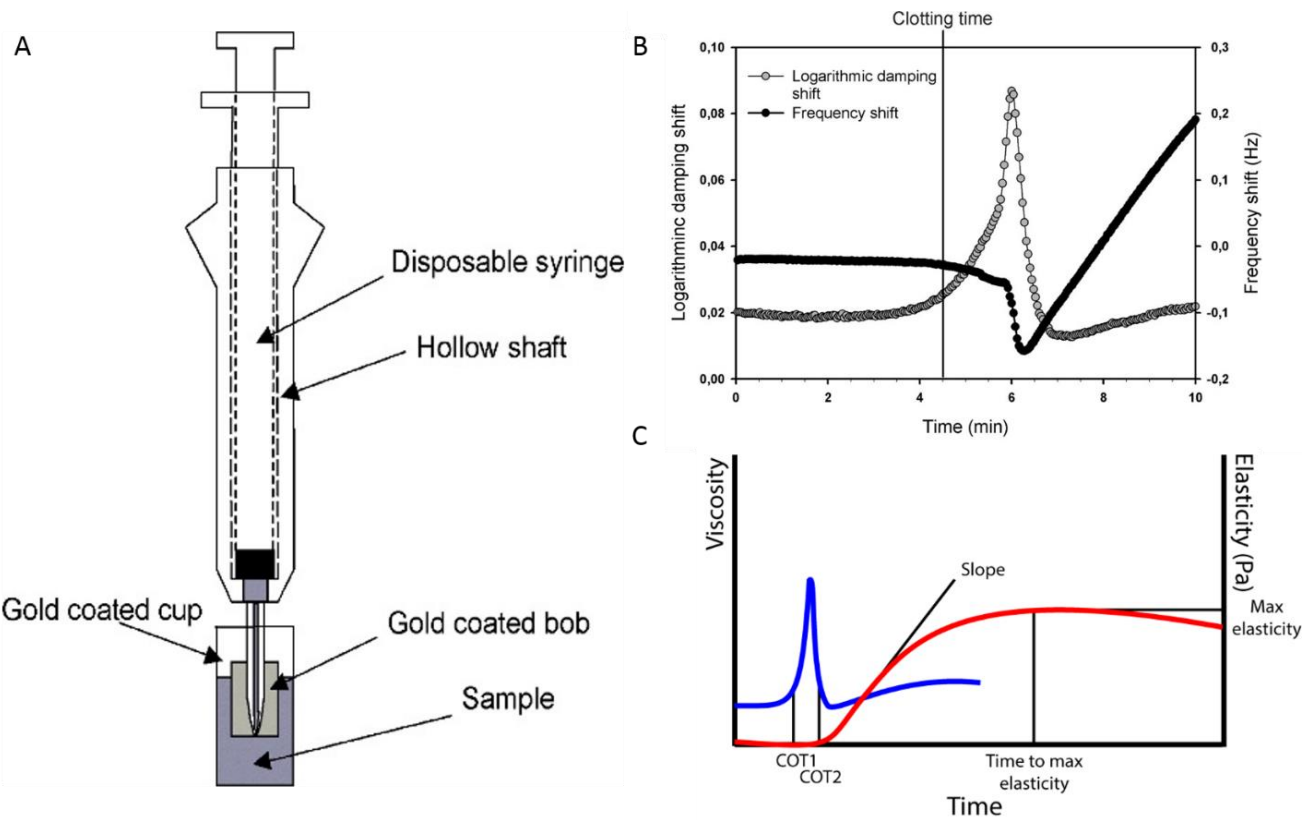

Figure 6. (A) Schematic presentation of a sample cup and bob. (B) A typical curve showing the shifts in damping and frequency data. (C) A typical viscoelastic FOR curve as seen in the instrument. The different parameters are denoted. (A and B from [96], reprinted with permission from Taylor and Francis).

$[96,156]$ and gives information on the maximum clot elasticity and time to reach maximum clot elasticity. The slope of clot elasticity changes is given as the change in elasticity/minute. All viscosity and elasticity parameters are calculated by the instrument. However, in Paper IV, the instrument parameters reported were sometimes inaccurate, due to disturbances in the measurements. Thus, visual inspection of the viscosity and elasticity curves were always performed to determine the parameter accuracy and were adjusted if needed. Slope was the parameter most affected by occasional measurement inconsistencies. To ensure that the slope parameter was equally determined for all samples, the slope was calculated manually as the change from elasticity at $300 \mathrm{~Pa}$ and the elasticity measured $60 \mathrm{~s}$ later [158]. A typical viscosity and elasticity curve as seen on the instrument is shown in figure 6C.

In Paper IV, whole blood was added to gold-coated sample cups (with bobs) containing platelet agonists. As such, the measurements reported reflect the difference in clotting and clot elasticity/clot retraction based on platelet activation responses. FOR measurements are also sensitive to other factors. Contact activation (i.e. activation of FXII leading to activation of FXI) may reduce the clotting time (COT1), which is why clotting occurs despite the absence of tissue factor. This is also the reason why blood samples for FOR measurements were 
collected in Monovette tubes and measurements initiated within 10 min from blood collection, as both of these factors reduce the degree of contact activation [160]. Other parameters that influence FOR elasticity parameters are platelet count, fibrinogen levels and severe changes in hematocrit [96]. As these parameters are also part of the in vivo donor parameters, these factors were not corrected for. However, platelet counts were recorded for the citrated Monovette tubes, and these correlated to maximum elasticity only $\left(\mathrm{R}^{2}=0.55, \mathrm{p}=0.0003\right)$.

\section{Flow cytometry}

\section{Principle}

Flow cytometry is an optical method used to individually investigate cells (or other particles) in suspension. It is composed of a fluidic system, designed to focus the cells which are then interrogated using a light source. The resulting scattering of light is measured and converted into a signal. (Section based on [161-164])

\section{Fluidics}

The sample is injected into a sheath fluid suspension which forms a "tube" around the sample. The sheath fluid is a non-fluorescent and particle free suspension. The pressure of the sample fluid is higher than the sheath fluid, forcing the cells in the sample to align at the center of the sheath fluid, in a laminar flow, thus passing the flow cell in a single file. This process is called hydrodynamic focusing and is essential for accurate data collection.

\section{Optics}

Single cells pass the detection point, where a laser beam is focused by lenses to a narrow area ensuring single cell illumination. Light reflected by the cell will be scattered in different directions. In addition to the scattered light, fluorescence can also be measured.

Forward scatter: Light scattered with little deflection from the cell. This is detected on the opposite side of the cell as compared to the origin of the laser beam. An obstruction bar is placed in front of the detector to block light coming directly from the laser, without deflection. The forward scatter corresponds roughly to the size of the cell. The light may be focused to the detector using collection lenses. The light is filtered before detection.

Side scatter: Light scattered by the cell with a high deflection (about $90^{\circ}$ ). Side scatter is collected perpendicular to the laser beam, and may be focused using collection lenses. Side scatter corresponds more or less to the granularity of the cell. The light is filtered before detection.

Fluorescence: Is often derived from fluorescently conjugated antibodies directed to an antigen on the cell of interest. Fluorophores are excited by a laser beam, and emits light of a higher wavelength. The light is emitted in all directions, but the 
fluorescence light is often collected perpendicular to the laser beam. A flow cytometer can be equipped with several lasers and detectors to allow information on a number of different fluorophores. Light of different wavelengths are directed towards the different detectors using a set of dichroic mirrors. The dichroic mirrors reflects light of a certain wavelength while allowing other wavelengths to pass through. The fluorescence signal confers information on the abundance of a fluorophore.

Detection: Stronger light signals from forward scatter (and sometimes side scatter) are detected using photodiodes, whereas the weaker fluorescent signals are detected using photomultiplier tubes. Light reaching the detectors is converted into a digital signal proportional to the light intensity of the cell.

\section{Flow cytometry and considerations for development of the 6-colour protocol}

As platelet subpopulations are precisely that, subpopulations, flow cytometry is a suitable method for their study. Where other methods often measure bulk values from an entire sample, flow cytometry measures a set of parameters on individual platelets. Due to the high throughput, data can be obtained for a large number of cells within a short timeframe. The small sample volumes required is another advantage of flow cytometry compared to many other methods.

Flow cytometry has been the main method during the thesis work, and our protocol is based on the whole blood protocol described by Shattil et al in 1987 [165]. Whole blood has often been our preferred platelet suspension, as it reduces the risk of handling artefacts such as preanalytical platelet activation. Throughout the thesis, our flow cytometry protocol has evolved in a stepwise manner. From a three-color protocol with two platelet gates to a more advanced protocol measuring 6 colors simultaneously and with a modified gating strategy. Preanalytical improvements have also been important for the overall usability of the method.

\section{Gating and platelet detection}

Determining the formation of platelet microparticles was planned from the beginning of the thesis work. The standard routine for detection of microparticles, was to set a gate including 1-2\% of the resting platelet population and all particles smaller than this [23, 24], figure 7A. However, due to the acquisition of a new flow cytometer with increased sensitivity for smaller particles, we observed that the standard gating did not fit our data. Instead of a continuous platelet cloud, we observed three populations of platelet-derived particles, Figure $7 \mathrm{~B}$, depending on the platelet stimulation used. As our data did not align with previous reports, we decided to use different denominations for the three platelet populations. The largest platelet population was called "Normal-sized platelets", the intermediate population was called "Smaller platelets" and the smallest population was called "platelet fragments". The formation of three platelet populations is supported by an earlier report by Tocchetti et al [67] identifying two populations of platelet 
A

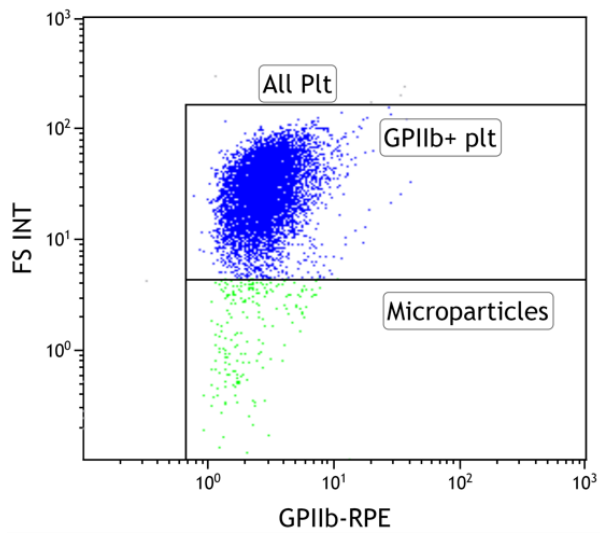

B

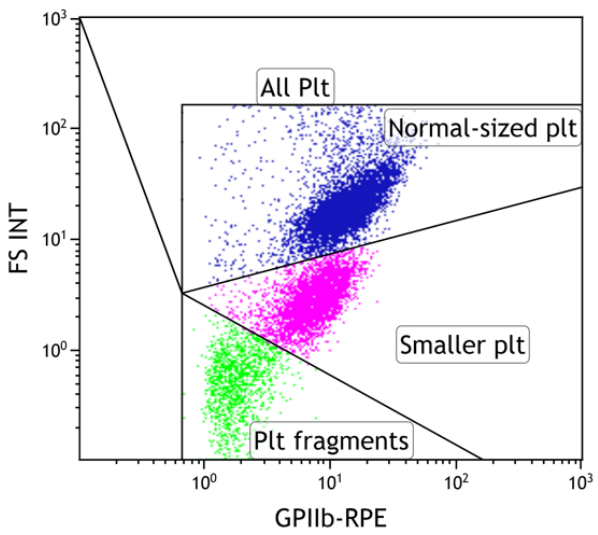

Figure 7. (A) A resting platelet sample with microparticle-gating according to the first strategy, as described in the text. (B) Platelets stimulated with $C R P-X L+P A R 1-$ $A P+P A R 4-A P$, with the modified gating strategy. Forward scatter (FS INT), Platelets (Plt), R-phycoerythrin (RPE).

microparticles, and by Bode \& Hickerson [68] indicating that microparticles reported in the literature often are too few and more likely correspond to smaller platelets.

\section{Platelet markers}

Platelets are small cells easily differentiated from other blood cells based on their size (forward scatter properties) alone. They are best identified using a logarithmic scale $[137,166]$. However the use of a fluorescently labelled platelet marker, and a fluorescence trigger for particle detection, improves the detection of smaller particles, such as platelet microparticles, Paper III [167, 168], and if the platelet marker antibody contains little debris, substantially decreases the detected background noise. The commonly used platelet detection markers are GPIb (CD42b), $\alpha I I b(C D 41 a)$ or $\beta 3$ (CD61) [137, 166, 169], which are the most abundant receptors on the platelet. Of these, $\alpha \mathrm{IIb} \beta 3$ is the most abundant platelet receptor, with at least $50000-80000$ copies per cell. aIIb (CD41a) is also uniquely expressed on platelets (and megakaryocytes) [16]. Expression level is an important parameter to consider when detecting microparticles, as the generation of microparticles will unavoidably lead to a reduction in receptor numbers as compared to the original platelet [170]. For these reasons, we chose to use an antibody towards aIIb as our platelet marker. GPIb has however been used as the platelet marker on some occasions, although not in the 6-color protocol. We did not experience any problems with platelet activation or interference with detection of $\alpha I I b \beta 3$ activation state, which is sometimes a concern, see Paper III. 
Table I. Platelet markers used in the 6-color protocol.

\begin{tabular}{|l|l|l|l|}
\hline \multicolumn{1}{|c|}{ Marker for } & Antibody/probe & \multicolumn{1}{|c|}{$\begin{array}{c}\text { Dye/(em. } \\
\text { wavelength) }\end{array}$} & Detector \\
\hline $\begin{array}{l}\text { Active } \alpha \mathrm{IIb} \beta 3 \\
\text { /aggregatory potential }\end{array}$ & PAC-1 & $\begin{array}{l}\text { FITC } \\
(520 \mathrm{~nm})\end{array}$ & FL1 \\
\hline a-granule secretion & P-selectin (AK-4) & $\begin{array}{l}\text { PE } \\
(578 \mathrm{~nm})\end{array}$ & FL2 \\
\hline Platelet marker & aIIb (P2) & $\begin{array}{l}\text { ECD } \\
(620 \mathrm{~nm})\end{array}$ & FL3 \\
\hline Lysosomal secretion & LAMP-1 (H4A3) & $\begin{array}{l}\text { PE-Cy7 } \\
(785 \mathrm{~nm})\end{array}$ & FL5 \\
\hline $\begin{array}{l}\text { Mitochondrial } \\
\text { membrane potential }\end{array}$ & DiIC1(5) & $\begin{array}{l}658 \mathrm{~nm} \\
(638 \mathrm{~nm})\end{array}$ & FL6 \\
\hline PS & Annexin V & $\begin{array}{l}\text { V450 } \\
(448 \mathrm{~nm})\end{array}$ & FL9 \\
\hline
\end{tabular}

In addition to a platelet marker, we have in a stepwise manner increased the number of platelet activation markers possible to detect. From a three-color protocol to a 6-color protocol, table I. In Paper I and II, measurements were obtained for LAMP-1/Annexin V or for LAMP-1/P-selectin (CD62P), in addition to the platelet marker. The $\alpha \mathrm{IIb} / \mathrm{LAMP}-1 /$ Annexin $\mathrm{V}$ combination was then extended, first to include PAC-1, subsequently followed by P-selectin. Upon acquisition of a third laser to the flow cytometer, it became possible to include a $6^{\text {th }}$ activation marker, 1,1',3,3,3',3'-hexamethylindodicarbocyanine iodide $\left(\operatorname{DiIC}_{1}(5)\right)$. The full protocol was used in Paper III and IV.

P-selectin is an integral membrane receptor located in a-granules. Upon platelet activation and $\alpha$-granule secretion, it is translocated to the platelet surface. Pselectin exposure is seen as a general platelet activation marker [166, 169]. LAMP1 is located in the lysosomal membrane. Its translocation to the platelet surface thus indicates lysosomal exocytosis. In contrast to LAMP-2 and CD63 which are found also in dense granules, LAMP-1 is a specific lysosomal marker [171, 172]. Similar to P-selectin, LAMP-1 may be used as a platelet activation marker, although it is less sensitive than P-selectin exposure, Paper I, II and III. As Pselectin and LAMP-1 are both detected using regular antibodies, background fluorescence was determined using isotype control antibodies, matched to the antibody concentration (and fluorescence/protein ratio when applicable), and compared to resting controls [137]. Annexin V is a probe that binds to PS with high affinity in the presence of $\mathrm{Ca}^{2+}[52,54,57,173]$. Lactadherin is another probe also detecting PS exposure, but in a $\mathrm{Ca}^{2+}$ independent manner [174-176]. We chose to use Annexin V, mainly because it is $\mathrm{Ca}^{2+}$ sensitive. This allows for the determination of the background fluorescence by simply omitting $\mathrm{Ca}^{2+}$ from the sample. PAC-1 is a monoclonal antibody which recognize the active conformation of $\alpha \mathrm{IIb} \beta 3$ [75]. Similar to Annexin V, a negative control is easily obtained by 
addition of EDTA to the sample as this dissociates the receptor [177]. This is useful, not only for PAC-1 but also for other strategies to determine the activation state of $\alpha I I b \beta_{3}$. The probe $\operatorname{DiIC}_{1}(5)$ preferentially accumulates in active mitochondria, if used in low enough concentration, where a fluorescent signal is indicative of a retained mitochondrial membrane potential [178, 179]. Carbonyl cyanide 3chlorophenylhydrazone (CCCP) can be used as a positive control $[178,179]$, although in our experience it is not always fully efficient.

With this combination of antibodies/probes, we are able to detect most of the common platelet features, including platelet activation state (P-selectin and LAMP-1 exposure) and most of the conventional procoagulant features (AnnexinV and PAC-1 binding, mitochondrial integrity and platelet fragmentation) in each performed experiment, thus removing the need for indirect comparisons.

\section{Setting the protocol}

When the antibody/fluorophore combinations have been determined, they need to be tested and titrated, often in several iterations. The antibody/probe concentrations should be chosen to saturate the antigen upon full exposure, while causing as little background fluorescence as possible [169, 180]. Concentrations almost invariably had to be reduced as compared to manufacturer recommendations.

Flow cytometer settings need to be determined for each protocol used. If the fluorophore abundance varies extensively between different experiments, the settings may need adjustment. These settings mainly involve determining the appropriate voltage settings for each of the fluorescence detectors involved, hence achieving a reasonable level of signal enhancement. The rule of thumb is that a negative histogram peak should be detected in the first decade [181], while a positive peak should be as separated from this as possible. Again, compromises may be required as settings in one detector will influence the degree of spectral overlap into another.

Multifluorescent flow cytometry entails the issue of spectral overlap [180, 181]. This means that the fluorescence from one fluorophore will "spill over" and not only be detected by the designated detector but also by a detector(s) for another fluorophore, hence compromising the separation of the fluorophores. To minimize this, the chosen fluorophores should be separated as much as possible, regarding the emission wavelengths. In addition, theory claims that abundant antigens should be detected using dim fluorophores, whereas less frequent antigens should be detected using bright fluorophores [180]. Some compromises have been required also with regards to this, mainly due to limitations of available antibodies/probes. PAC-1 for instance is only available as a fluorescein isothiocyanate (FITC)-conjugate, whereas Annexin V sensitivity (in our experience) was reduced with R-phycoerythrin (PE) dyes. The remaining spectral overlap is corrected through compensation analysis [181]. Compensation analysis is best performed using samples labelled with each fluorophore separately. In this 
way, the spectral overlap from each fluorophore into other detectors can be determined [180, 181]. It is also useful to run fluorescence-minus-one (FMO)samples, including all fluorophores except one. With these samples it is possible to determine the total degree of spectral overlap into each of the detectors. I think the most useful approach is to first run singly labelled samples, to set the compensation, followed by FMO-samples as a control, and to fine tune the compensation matrix if needed.

\section{Data analysis}

Gating for size was determined as described above. Staining patterns were determined using isotype and negative controls to delimit the positive and negative populations. The positive gate was set to include 1-2 \% of cells in the negative peak [137, 182]. Expression levels were also determined using median fluorescence intensity (MFI) in the entire population [137].

\section{Preanalytical improvements}

The flow cytometric method used has also involved a number of preanalytical developments. As Annexin V binding to PS is $\mathrm{Ca}^{2+}$ dependent, it is mandatory to use a buffer containing $\mathrm{Ca}^{2+}$. In the literature, a $\mathrm{Ca}^{2+}$ concentration of $2-3 \mathrm{mM}$ is common $[57,63]$. As $\mathrm{Ca}^{2+}$ is an important parameter in platelet response we have chosen to reduce this to $1.5 \mathrm{mM} \mathrm{Ca}{ }^{2+}$, which is slightly above the physiological plasma concentration of $1.2 \mathrm{mM}$ [136]. Annexin V-binding has been reported to increase with the $\mathrm{Ca}^{2+}$ concentration, where $1.5 \mathrm{mM}$ corresponds to half-maximal binding to phospholipid vesicles containing 20\% PS [173]. We have not experienced any problems with this lower concentration, neither during testing nor after.

Other improvements have been more of the practical sort. Sample tubes are now prepared by the preparation of mastermixes, which reduces the inaccuracy due to pipetting errors. When an individual experimental protocol has been set, flow cytometry tubes with agonists are normally prepared for several rounds and stored in the freezer. These are also prepared through mastermixes, again reducing inaccuracies and between experiment variations. In addition, it substantially reduces the preparation time required for each experiment. 


\section{Results and discussion}

\section{Characterization of platelet subpopulations}

\section{Lysosomal exocytosis in platelets}

As mentioned previously, platelets have three types of granules that are secreted upon activation, $\alpha$-granules, dense granules and lysosomes. Among these, $\alpha$ - and dense granules are the most studied. Both $\alpha$ - and dense granules play important roles in hemostasis, as defects in these give rise to bleeding syndromes [16, 183]. Hence, much research has been focused on these granules. In contrast, the role of lysosomal secretion is not as well known. LAMP-1 exposure has been demonstrated in platelets obtained from a bleeding wound, indicating that lysosomal secretion occurs "in vivo" [184]. In Paper I, we wished to investigate the extent and regulation of platelet lysosomal release.

Platelet activation with thrombin led to rapid lysosomal secretion, detected as increased $N$-actetyl- $\beta$-glucosaminidase (NAG) activity and platelet LAMP-1 surface exposure. Maximal NAG activity and high LAMP-1 exposure was achieved with 1 min stimulation. We found that inhibition of platelets with the $\mathrm{P}_{2} \mathrm{Y}_{12}$ inhibitor cangrelor reduced NAG activity to that of the resting control $(\sim 10 \%)$ as well as reduced LAMP-1 exposure to 27\% (47\% without inhibitor). Exposure of the activation marker P-selectin was also reduced by cangrelor, but only to a small extent. COX-I inhibition with ASA did however not impact the results in the present experiments. Endothelial platelet inhibitors PGI2 and the NO-donor SNitroso- $N$-acetyl-DL penicillamine (SNAP) were both able to reduce platelet lysosomal secretion. PGI2 reduced NAG to $17 \%$ compared to $25 \%$ without inhibitor and LAMP-1 to the level of the resting control. SNAP reduced NAG to $16 \%$ whereas LAMP-1 exposure was $11 \%$, compared to $30 \%$ without inhibitor. In addition to lysosomal secretion, PGI2 and SNAP also reduced P-selectin exposure and SNAP led to a general reduction in platelet activation, seen as reduced platelet aggregation and reduced dense granule secretion (ATP secretion).

In Paper II, LAMP-1 exposure was investigated in platelet concentrates after increasing storage time up to 12 days. In the study, we found that LAMP-1 exposure in resting platelet samples remained stable and low throughout the storage time (with a mean of $6 \%$ on day 12). However, as the storage time increased, the exposure of LAMP-1 in response to agonist stimulation was gradually reduced for all agonist combinations. In platelet concentrates where swirling had been lost, exposure of LAMP-1 in response to platelet stimulation was abolished. In conclusion, this makes LAMP-1 an interesting candidate marker to monitor the quality of platelet concentrates in vitro. 
Lysosomal exocytosis and platelet subpopulations

Since lysosomal secretion and platelet PS exposure are both partial and require strong agonist stimulation, we also aimed to investigate whether such platelets constitute the same platelet subpopulation. This was investigated using flow cytometry. As shown in figure 8 (unpublished results), LAMP-1 exposure was detected in platelets with and without PS exposure and these markers seemed to be exposed independently of each other.

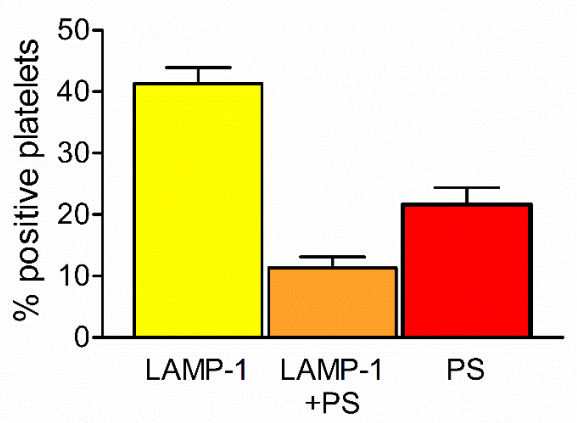

Figure 8. Platelet exposure of LAMP-1 and PS was measured simultaneously using flow cytometry. Yellow and red bars correspond to total exposure of LAMP-1 and PS, respectively. The orange bar correspond to cells exposing both LAMP-1 and PS. Results indicate that LAMP-1 and PS were exposed by separate platelet populations. Platelets were stimulated for 10 minutes with PAR1-AP (3O $\mu M)$ PAR4-AP (15O $\mu M)$ and CRP-XL $(0.9 \mu \mathrm{g} / \mathrm{ml}) . \mathrm{N}=5$, mean \pm SEM.

\section{Procoagulant platelets (features of procoagulant and aggregatory platelets]}

Exposure of PS on the platelet membrane provides a procoagulant surface for coagulation factors to adhere. PS exposure can be detected in vitro with the use of Annexin V [52, 54, 173]. As discussed in Papers II, III and IV platelets binding Annexin V are therefore regarded as procoagulant. Exposure of PS and other markers of activation were compared between the different platelet populations. We observed that PS exposure was primarily found on smaller platelets and platelet fragments (Paper II and III). Similar results were reported by Sims et al [61], who observed that FV binding was increased on microparticles. In line with this, some studies have found that microparticles are more procoagulant than platelets [61], whereas others have found the opposite [23]. As discussed in Paper III, the smaller platelets observed in our study probably correspond to the particles described as microparticles in earlier studies [57, 58, 61]. We hypothesize that platelets that become activated enough to transition into the procoagulant phenotype, release platelet fragments, which is supported by previous observations of ballooning platelets $[59,63,65,70]$. Upon release of platelet fragments, the size of the remaining platelet would be reduced and hence be detected as a smaller platelet. This theory is supported by Tocchetti et al, who 
describe two populations of platelet "microparticles" [67], and Bode \& Hickerson who suggested that the number of "microparticles" described in earlier studies are too few and thus rather constitute small platelets [68]. The fact that a third population of platelet microparticles has not gained more attention in earlier studies is likely attributed to an increased sensitivity of more recent flow cytometers. Another important factor is likely the use of a fluorescence trigger based on a platelet marker, which increases the detection sensitivity. In addition to PS exposure, the procoagulant smaller platelets and platelet fragments have a reduced binding of $\mathrm{PAC}-1$, indicating that $\alpha \mathrm{IIb} \beta 3$ is not in an active conformation or inaccessible to the antibody, in agreement with previous studies $[71,74,76]$. However, as discussed in Paper III (and shown in Paper IV), platelets with a reduced PAC-1 binding may still bind an anti-fibrinogen antibody, indicating that fibrinogen is retained on the surface. Whether this is bound to the surface via $\alpha \mathrm{IIb} \beta_{3}$ or to other receptors via the binding of a multiprotein complex (as suggested by Szasz \& Dale [72]) cannot be determined from these experiments. Mitochondrial potential was also measured using the probe $\operatorname{DiIC}_{1}(5)$. A reduced staining in procoagulant platelets suggested that mitochondrial potential was lost in these platelets, which is in line with previous research [73, 87-89]. On the contrary, platelets without PS exposure, hence not binding Annexin V, retained the size of resting "normal-sized" platelets. The normal-sized platelets had a high binding of PAC- 1 and retained the majority of $\operatorname{DiIC}_{1}(5)$ fluorescence, suggesting an active $\alpha \mathrm{IIb} \beta 3$ and intact mitochondrial potential in these platelets.

Upon platelet stimulation, all platelets would respond by a-granule secretion, seen as a universal exposure of P-selectin, ensuring that all platelets had been activated. Exposure of LAMP-1, indicative of lysosomal secretion was detected to a lesser degree, but with a similar pattern as P-selectin. Thus, we interpret that lysosomal exocytosis may also be regarded as a platelet activation marker in a similar way as P-selectin exposure. However, as lysosomal exocytosis requires a higher level of agonist stimulation before it is secreted, it also infers a higher level of platelet activation. As such, LAMP-1 is useful as a complementary activation marker to Pselectin exposure. Exposure of LAMP-1 may however be obscured by the fact that all platelets do not contain lysosomes [12], therefore restricting the maximum level of platelets exposing LAMP-1. In previous studies, lysosomal exocytosis has been detected using LAMP-2 or LAMP-3 (also called LIMP/CD63), but since these have been shown to be present also in dense granules $[12,171,172]$ they are not specific for lysosomal exocytosis.

\section{Different factors influencing the platelet response}

\section{Agonists}

The agonists chosen to induce the formation of procoagulant platelets influences the results obtained. This has been noted in previous publications, indicating that different agonists have different potencies $[23,24,57]$. We have observed a similar 
variation in potency between the used agonists (Paper II and III). Thrombin stimulation, for $10 \mathrm{~min}$, induced only low levels of PS exposure, in line with previous reports [23, 24, 57]. However, upon longer times of stimulation, the potency of thrombin increased. This might be due to alternative pathways of PS exposure $[46,185]$. It is generally thought that PS exposure in response to platelet activation occurs via a necrosis-like process $[185,186]$. The increased potency of thrombin with longer stimulation times might indicate that PS exposure induced via thrombin rather induces an apoptotic pathway. In support of this, it has been reported that the level of PS exposure due to apoptosis is slower than PS exposure induced by necrosis [187].

As mentioned in the introduction, the level of intracellular $\mathrm{Ca}^{2+}$ is important for the subsequent platelet response [58, 59, 63, 70]. The use of different platelet inhibitors affecting the $\mathrm{Ca}^{2+}$ mobilization will therefore influence the fraction of procoagulant platelets obtained. In an experiment using cangrelor to inhibit the APD-receptor $\mathrm{P}_{2} \mathrm{Y}_{12}$, we observed that inhibition of the second wave of stimulation resulted in a reduced fraction of procoagulant platelets, figure 9. Platelet inhibition with ASA was, however, without effect in these experiments. The role of ASA was found to be of minor importance also when studying the formation of procoagulant platelets adhered to collagen [59]. ASA is a common anti-platelet agent, the in vivo role of which may be different from that observed in these in vitro experiments.

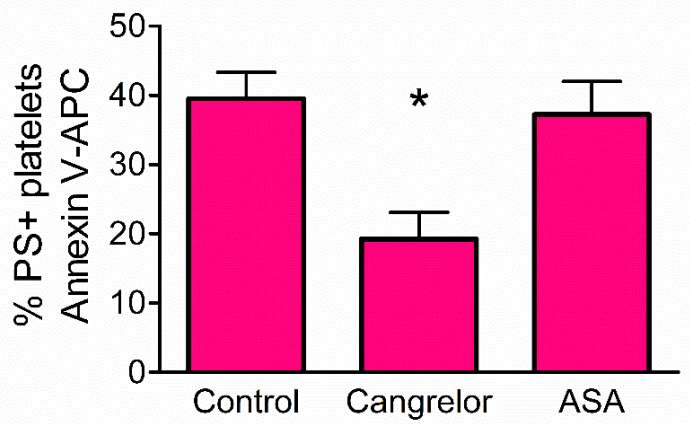

Figure 9. Effect of the platelet inhibitors cangrelor (P2Y12-inhibitor, 10o $\mu M)$ and ASA

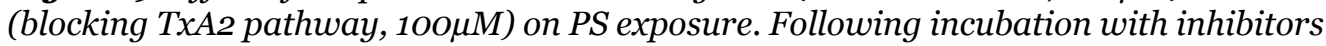
(2O min) platelets were stimulated, $10 \mathrm{~min}$, with CRP-XL $(1.2 \mu \mathrm{g} / \mathrm{ml})+P A R 1-A P(3 O$ $\mu M)+P A R 4-A P(300 \mu M)$. Mean $\pm S E M, N=4{ }^{*}$ indicate significant differences $v s$ control $\left({ }^{*} P<0.05\right)$.

\section{Platelet subpopulations}

In Paper III, we also aimed to discern whether the procoagulant platelets are in fact a subpopulation of platelets, or whether the responses seen rather correspond to a normal distribution related to the platelet activation status. If the responses are normally distributed and all platelets may in fact reach a state of activation leading to a transition into a procoagulant phenotype, then stronger platelet 
stimulation should be able to push all platelets over this threshold. To investigate this, we performed dose-response experiments using thrombin and CRP-XL alone or in combination. The formation of procoagulant platelets increased up to a plateau level (with a mean of $42 \%$ PS+ platelets), after which higher agonist concentrations did not influence the response. To further increase the level of activation, we increased the time of stimulation. This resulted in a higher proportion of platelets becoming procoagulant, but we did not reach 100\%. Thus, all platelets are not able to become procoagulant indicating that there is a subpopulation of platelets to whom this phenotype is "available". The transition into a procoagulant state is, nonetheless, heavily dependent on the level of platelet activation reached, and this response may be normally distributed.

\section{Platelet age}

As young platelets are claimed to be more reactive than older platelets $[23,104$, 105] we wished to look into this. However, as labelling of mRNA with TO is not straight forward [107, 188], in Paper II, we took an alternative approach to this problem and instead studied platelet concentrates. Platelets will remain in the circulation for up to 10 days $[3,6]$. Thus, a fresh platelet concentrate prepared from a healthy donor will consist of a mixture of platelets up to 10 days old. Whereas in platelet concentrates stored for some time, all platelets will eventually be old. In Paper II, we investigated if platelet storage time (and inherently platelet age) would affect the platelet procoagulant response towards agonist stimulation. We found that platelet responsiveness was reduced with platelet storage time. This was noted as a gradually reduced exposure of PS and LAMP-1 in response to platelet agonist stimulation. At the same time, we also noted a gradually increasing exposure of PS and P-selectin in resting platelet samples. This approach is however not without limitations. As platelet concentrates are processed and stored in an artificial milieu, and this in itself will result in platelet impairments [189], these results are not easily interpreted. It has also been argued that platelet aging is much slower during storage at $22^{\circ} \mathrm{C}$, compared to in vivo conditions at $37^{\circ} \mathrm{C}$ [130]. The results of Paper II with regard to the effect of platelet age on platelet responsiveness must unfortunately be deemed inconclusive.

\section{Platelet size}

Similar to platelet age, it has been speculated that younger platelets are larger than older platelets, and for this reason these platelets would be more reactive than smaller platelets [190, 191]. But this hypothesis has been contradicted by Thompson et al, who show that young platelets are not necessarily larger than older platelets $[104,192]$. Platelet size is rather determined during production $[104,188,192]$. It has however been reported that larger platelets are more reactive than smaller platelets, with regards to platelet aggregation [104, 191] and PS exposure [107]. As the platelet count is inversely correlated to mean platelet volume (MPV) it seems feasible that large platelets would be more reactive than smaller ones [188, 193-195]. 
In line with this, a high MPV has been associated with thrombotic events [195-197], although it is not known whether this increased MPV is a causative risk factor for cardiovascular disease or a result of underlying physiological factors [197]. MPV is however difficult to assess, especially in clinical studies due to anticoagulantinduced swelling of platelets $[194,198]$. It is therefore important to standardize the time from blood collection to performance of the MPV measurements [194].

We have investigated the effect of MPV on platelet reactivity using two strategies. In the first set of experiments, we centrifuged whole blood to PRP and isolated the top fraction containing smaller platelets and the bottom fraction containing larger platelets. The large and small platelets were then stimulated and exposure of Pselectin, PS and active conformation of $\alpha \mathrm{IIb} \beta 3$ was detected using flow cytometry. We found an increased exposure of $\alpha \mathrm{IIb} \beta 3$ and P-selectin on larger platelets, figure 10 (abstract [199]). For PS, the exposure was higher in smaller platelets when weak agonists were used, but this difference was not significant when stronger agonists were applied. This indicates that larger platelets may indeed have a higher aggregatory potential than smaller platelets, probably related to a higher number of platelet granules [192].
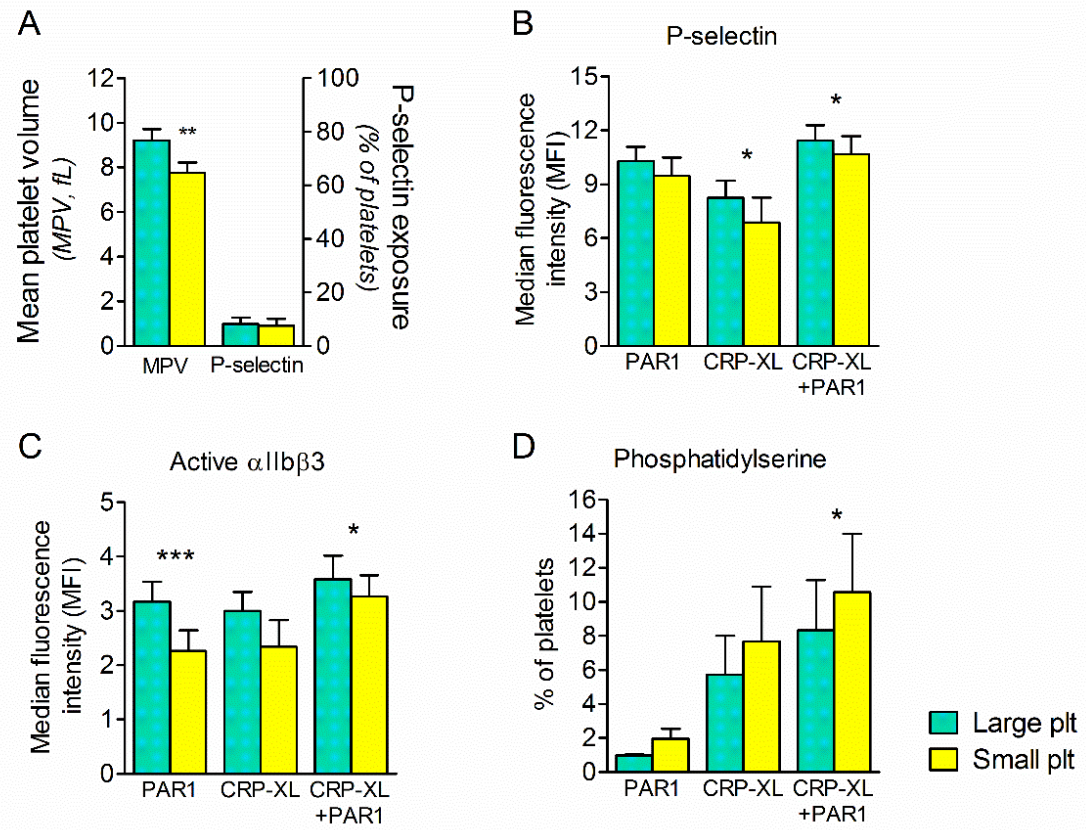

Figure 1o. (A) MPV and resting P-selectin exposure. (B) Platelets were stimulated and exposure of P-selectin, (C) active aIIb $\beta 3$ or (D) PS was determined using flow cytometry. PAR1-AP (3O $\mu M), C R P-X L(0.5 \mu \mathrm{g} / \mathrm{ml})$ or both were used for platelet stimulation. * indicate significant differences between the large and small platelet fractions $(* * * *=P<0.05,0.001) . N=6$, mean \pm SEM. 
In Paper IV (not included in manuscript) we also measured the platelet MPV in EDTA anticoagulated blood $3 \pm 2$ min (maximum $7 \mathrm{~min}$ ) after blood collection. When compared to platelet PS exposure, we found a weak but significant positive correlation to MPV $\left(\mathrm{R}^{2}=0.17, \mathrm{P}=0.043\right)$, figure 11 .

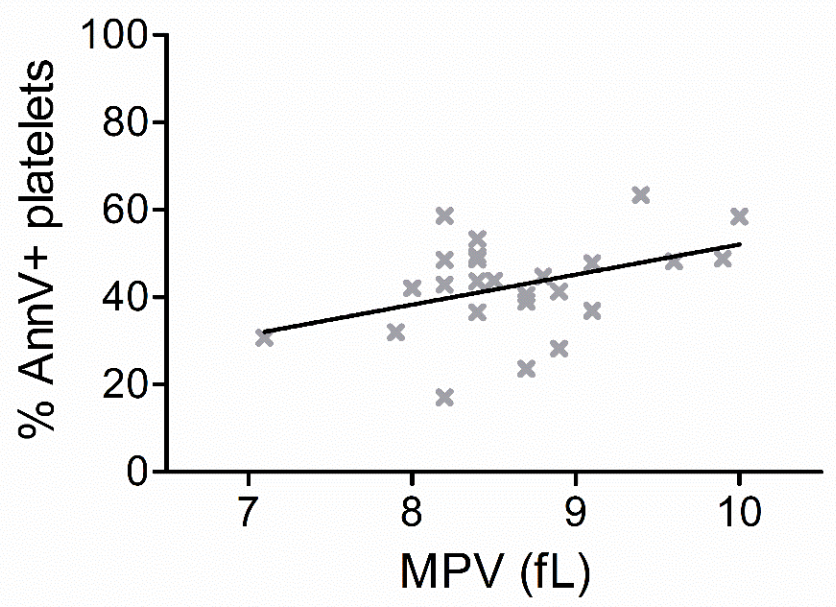

Figure 11. Association between platelet PS exposure and $M P V, N=25$.

\section{Relevance of platelet subpopulations}

\section{Platelet concentrates}

In Paper II, we found that the generation of procoagulant platelets in response to agonist stimulation was reduced with storage time. This was detected as a reduced platelet fragmentation and a reduced level of PS exposure. The exposure of LAMP1 in response to agonist stimulation was also reduced, whereas LAMP-1 exposure in resting samples remained stable over the storage period. We noted a variability in the level of LAMP-1 exposure in platelet concentrates with retained swirling. Whereas platelet concentrates without swirling were unable to expose LAMP-1 or fragment into smaller platelets and platelet fragments in response to agonist stimulation. Hence LAMP-1 exposure and platelet fragmentation in response to agonist stimulation may be useful to evaluate the quality of stored platelet concentrates. Although our study does not pinpoint the exposure of P-selectin and PS as clear markers of platelet responsiveness, these markers have been used in the past and may be useful also in future studies [189]. 


\section{Influence on hemostasis}

In Paper III, we observed that the procoagulant plateau response varied heavily between individuals, with a range of 20-66\% Annexin V+ platelets (42 $\pm 16 \%$ mean \pm SD). Similar numbers were found in Paper IV (range 17-63\%, mean $43 \pm 11 \%$ ). A variation in the level of coated platelets in healthy volunteers was also reported by Dale et al (range 15-53\%, 33.0 $\pm 9.3 \%$ ) [200], and was shown to be stable over a 6-week period. The level of coated platelets have additionally been correlated with several cardiovascular conditions. Increased numbers of coated platelets correlated with thrombotic events [201-203] whereas reduced numbers correlated with hemorrhagic events [204-206]. Correlations have also been found for other conditions, such as Alzheimer's disease [207]. Most of these studies have been performed by a single research group, which accentuates the need for independent validation. A potential pitfall in these studies is the fact that the level of coated platelets is measured in these patients shortly after an event has occurred. Thus it is not unlikely that the various conditions of the patient might influence the results.

In Paper IV, we instead investigated how the ability to form procoagulant platelets influenced different aspects of hemostasis in healthy volunteers. Procoagulant parameters were measured with CAT and FOR. The fraction of procoagulant platelets formed correlated to the CAT parameters peak $\left(\mathrm{R}^{2}=0.65\right)$ and inversely to time to peak $\left(\mathrm{R}^{2}=0.42\right)$, lagtime $\left(\mathrm{R}^{2}=0.22\right)$ and the FOR parameters COT1 and COT2 $\left(\mathrm{R}^{2}=0.13\right.$ and $\mathrm{R}^{2}=0.1$, respectively). There was no correlation to ETP. From this, we conclude that there is an association between the fraction of procoagulant platelets formed and the ability of platelets to support rapid thrombin generation. Although ETP may be regarded as the most robust parameter of CAT [153], Monroe and Hoffman suggested that the rate and peak thrombin reached may in fact be more important for clot stability than the total thrombin generated [31].

As procoagulant platelets have a reduced ability to form platelet-platelet connections (see Description of the procoagulant platelet), we hypothesized that this might be correlated to a reduced aggregatory potential. Thus aggregatory potential was assessed using Multiplate $\AA$ for whole blood aggregometry and LTA for conventional aggregometry in PRP. We found no correlation between the fraction of procoagulant platelets formed and Multiplate ${ }^{R}$ parameters, whereas we found a very weak correlation to \% maximum aggregation using LTA $\left(\mathrm{R}^{2}=\right.$ o.o8). The absence of correlations seen for these methods might have several explanations. As mentioned above, the procoagulant platelets may still bind fibrinogen although PAC-1 binding is reduced, hence they may be able to participate in aggregation responses by binding to the periphery of platelet aggregates. Another possibility is that the procoagulant platelets become translucent as a result of extensive granule secretion and ballooning, and therefore transmit light in a similar way as an aggregated platelet sample [73], although this would only be applicable to the LTA results. Another possible explanation is the time needed from activation to the transition into procoagulant platelets. Alberio 
et al recently reported that the time required for detection of procoagulant platelets was around 3 minutes from agonist stimulation [208]. Similar lagtimes have been observed in other studies, mostly evaluating adherent platelets [23, 49, 59, 64, 70, $76]$. As the aggregation response in both LTA and Multiplate $₫$ is measured within a few minutes from activation, it is possible that the platelets had not yet transitioned into a procoagulant state, and thus were still able to participate in the aggregation.

Because procoagulant platelets have been reported to be unable to participate in clot retraction, we analyzed this using FOR. Clot elasticity, as measured by FOR, is primarily influenced by the platelets contribution to clot retraction [96]. However, in Paper IV, clot elasticity did not correlate to the fraction of procoagulant platelets formed. It has been shown previously that clot elasticity is affected by the platelet count and plasma fibrinogen concentration [96]. In Paper IV, these parameters were regarded as part of the inherent physiological milieu of each donor and hence not corrected for. Although, additional comparisons show that the platelet count was strongly correlated to the maximum elasticity $\left(\mathrm{R}^{2}=0.59, \mathrm{P}\right.$ $=0.0001$ ), whereas fibrinogen levels were not measured.

As high cholesterol levels are a known risk factor for cardiovascular disease, we wanted to explore if there was a correlation between this and the ability to form procoagulant platelets. High levels of cholesterol will also lead to platelet hyperreactivity, but most studies investigate platelet aggregation [209, 210]. Interestingly, an increase in $\mathrm{Ca}^{2+}$ mobilization was reported in cholesterol loaded platelets [211]. Cholesterol depletion on the other hand, reduced platelet aggregation, $\mathrm{Ca}^{2+}$ mobilization [212] and platelet PS exposure [213]. One study also report increased thrombin generation in hypercholesterolemic patients compared to controls [214]. In Paper IV, we found a weak correlation between PS+ platelets and plasma cholesterol $\left(\mathrm{R}^{2}=0.17\right)$. Although our results were influenced by an outlier data-point, we chose to include this in our analysis. We noted however that an analysis without this data-point would have found a stronger correlation to cholesterol, and additional correlations to non-HDL cholesterol and LDL cholesterol.

Paper IV indicates that the ability to form procoagulant platelets influence hemostasis, especially parameters related to thrombin generation. Based on our results and previous publications, it is not impossible that the individual ability to form procoagulant platelets may in fact influence the individual risk of suffering from cardiovascular events. Further studies would of course be needed to prove this hypothesis, and if proven, to evaluate the strength of this as a risk factor. 


\section{My view on platelet subpopulations in clot formation}

Platelets have several functions in the hemostatic process that are important for the cessation of bleeding, formation of the platelet plug and support of coagulation. During the last decades, it has become clear that different functions are performed by different subpopulations of platelets. The procoagulant subpopulation of platelets vary in proportion depending on agonist stimulation. In vitro studies have also shown that the fraction of procoagulant platelets vary between individuals. As has been mentioned by others, individual platelets are either procoagulant or not, where intermediate states are rarely seen. As such, the factor determining the extent of the procoagulant response, is the number of platelets that become procoagulant [70, 87]. Although the complexity of an in vivo system is in many ways different from the simplified models used in in vitro experiments, it seems reasonable to think that in vitro variations of procoagulant potential may persist also in vivo, albeit at a different level than observed in vitro.

\section{The first layer[s] of platelets}

In vivo platelet activation occurs following vessel damage and exposure of the ECM. Platelets adhere via e.g. immobilized vWF, and those adhering to collagen fibers become activated via GPVI. Simultaneously, TF exposed at the site of damage has initiated the coagulation cascade via formation of the extrinsic tenase complex and is generating small amounts of thrombin. This thrombin will activate adjacent platelets and additional coagulation factors (FV, FVIII, FXI). The platelet activation induced via thrombin and collagen leads to platelet secretion. The release of granule contents (ADP) and TxA2 reinforces the platelet activation. This causes a shift in integrin affinity resulting in firm adhesion to the ECM, and binding of fibrinogen and vWF. The multifactorial platelet stimulation will cause a number of platelets to become procoagulant, figure 12A. The initial lagtime in procoagulant transformation ensures that these platelets are firmly adhered and to some extent covered by a second layer of platelets before the transition. The formation of a cap also ensures that these platelets are not immediately detached and removed by the flowing blood. As a-granules have also been secreted, the released and plasma derived FV will bind to the exposed PS, and the thrombin generation will move to the surface of the procoagulant platelets, figure 12B. Platelet swelling and microparticle shedding that occurs simultaneously as PS exposure may have different functions, which I can only speculate about; (1) To maximize the procoagulant surface, thus further enhancing thrombin generation. (2) Swelling may contradict the clot retraction, thus allowing agonist diffusion through gaps around the "balloon". (3) Formation of microparticles that may dissipate through the platelet thrombus to "spread" the procoagulant surface, thus facilitating thrombin generation and fibrin formation at other sites in the thrombus. (4) Microparticle shedding and dissipation may reduce the availability of the procoagulant surface, hence limiting the thrombin generation, to avoid overproduction of thrombin. (5) Microparticle shedding functions to "communicate" with adjacent cells and plays no direct role in hemostasis. 
The locally generated thrombin increases the thrombin concentration, which may induce a procoagulant transformation in additional platelets. The agonist dependence of the platelet procoagulant transformation ensures that the extent of vessel damage and hence collagen and TF (thrombin) exposure results in a proportional platelet response, and thrombin generation.

The recruitment

Additional platelets adhering to the growing thrombus will adhere to a plateletcoated surface via binding of vWF and fibrinogen retained via $\alpha \mathrm{IIb} \beta 3$ and GPIbIX-V, whereas collagen-interactions are no longer available. Released ADP, TxA2, as well as diffused and locally produced thrombin, will activate the adhered platelets and induce firm adhesion and additional platelet secretion, facilitating yet further platelet recruitment. The thrombin formed will cleave the fibrinogen bound to the platelets surface. Hence the platelet aggregate functions as a scaffold for the fibrin network. As platelets in additional layers of the thrombus have been promptly activated, binding of fibrin(ogen) to $\alpha \mathrm{IIb} \beta 3$ induces clot retraction in platelets with intact $\alpha \mathrm{IIb} \beta 3$, making the clot denser. This reduces agonist diffusion through the clot, and agonists such as thrombin are hence retained within the thrombus core, figure $12 \mathrm{C}$.

As the platelet plug grows, the soluble agonists also decrease in concentration. In the periphery of the clot, ADP and TxA2 will be the only available agonists. Hence the platelet activation level will decrease with the distance to the vessel wall. Eventually, the activation stimuli will be too weak to cause platelet secretion, and additional platelets will adhere transiently to the thrombus and then detach.

\section{Clot remodeling}

The higher concentrations of thrombin found within the densely packed thrombus core will activate FXIII, which will guide fibrin formation [77] and crosslink the thin fibrin strands into thicker, more resistant fibrin fibers. In addition, thrombin will activate TAFI, which counteract fibrinolysis and early dissolution of the clot. 
A
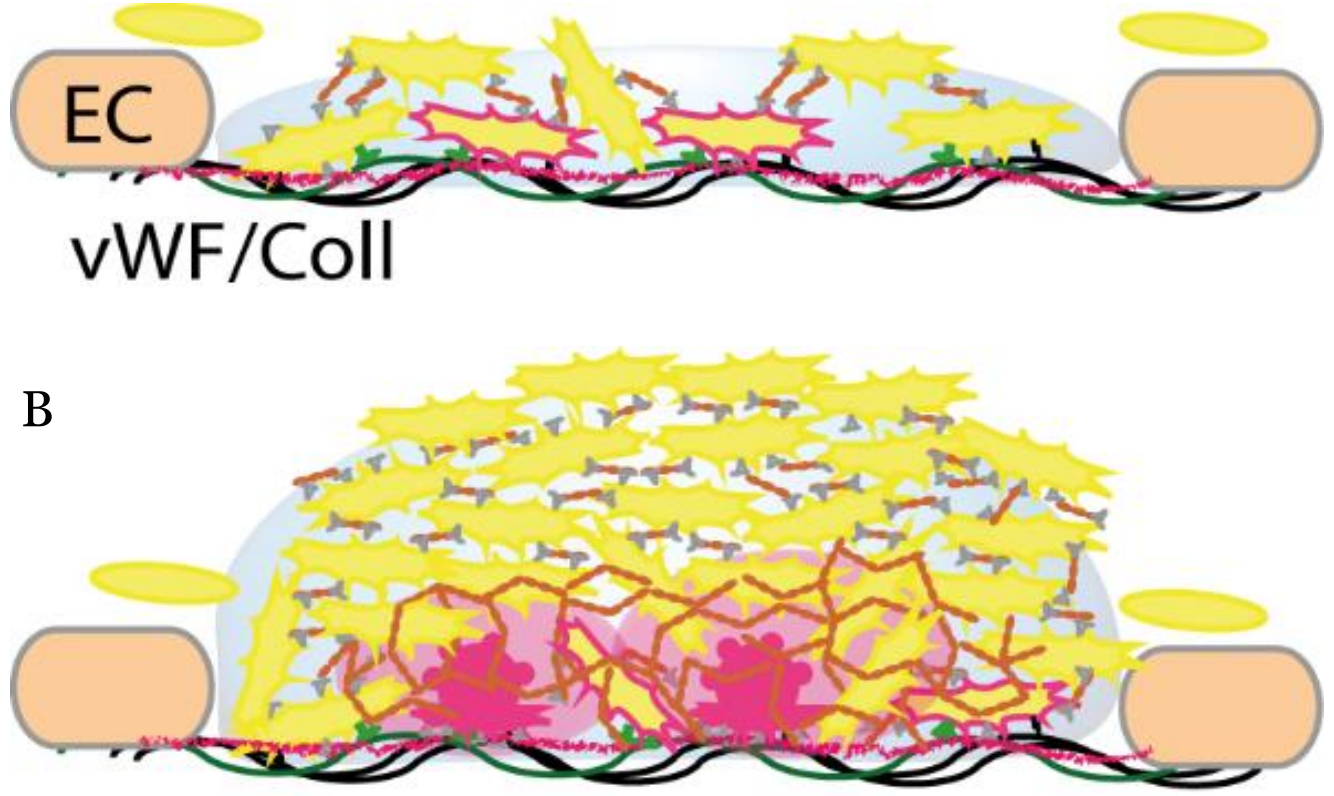

C

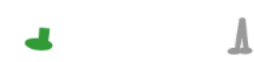

ADP/TxA2 GPIb-IX-V allbß3 GPVI Fibrin(ogen)

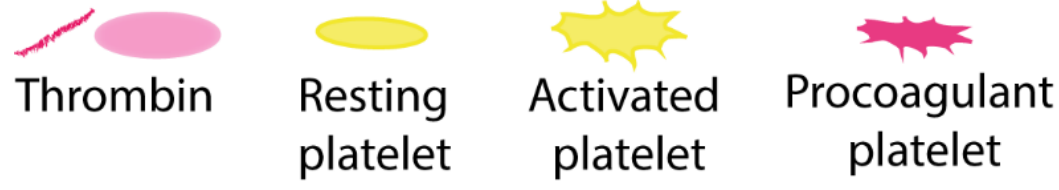

Figure 12. Illustration indicating the function of platelet subpopulations in hemostasis from (A) adhesion, (B) aggregation and coagulation to (C) clot retraction. Endothelial cell $(E C)$, von Willebrand factor ( $v W F)$, collagen (coll). 


\section{Potential consequences}

As outlined above, the different functions performed by platelets (aggregation and procoagulant behavior) are both crucial for a functional hemostatic response. Complete inhibition of one function is likely to cause severe adverse outcomes. However, as the fraction of procoagulant (coated) platelets have been associated with cardiovascular disease, one may speculate about the effect of different proportions of platelet subpopulations. A lowered ability to form proagulant platelets would reduce the potential for thrombin generation. This could result in a platelet aggregate with reduced fibrin formation, weak fibrin strands vulnerable to fibrinolysis, and increase the risk of rebleeding. It is conceivable that the thrombus core would also be reduced in size. In contrast, a high potential for the formation of procoagulant platelets would increase the thrombin generation and could hence increase the size of the thrombus core and produce a fibrin clot highly resistant to fibrinolysis, perhaps increasing the risk for thrombotic events. On the other hand, an extremely high potential for a procoagulant transformation may reduce the aggregatory response, which would lead to dissipation of thrombin and other soluble agonists. This may result in local bleeding, as the site of damage may not be satisfactorily covered. Depending on the potential of the antithrombotic system, the dissipated thrombin may also result in off target thrombus formation.

\section{Conclusion}

During the course of this thesis we have explored different aspects of platelet subpopulations. We have shown that lysosomal secretion, seen as LAMP-1 exposure occurs in a subpopulation of platelets, which is separate from the procoagulant platelet subpopulation. We suggest that LAMP-1 exposure and the formation of procoagulant platelets may be useful as quality indicators in the field of transfusion medicine. Through the development of a novel flow cytometry protocol it was possible to retrieve more information from each experiment. Using this protocol we have shown that the procoagulant platelet subpopulation is formed in response to strong platelet stimulation, and that the proportion of this varies extensively between individuals. Moreover, we show that the procoagulant subpopulation influences hemostasis, where it is primarily important for the rate of thrombin generation. Interestingly the procoagulant subpopulation was associated with plasma cholesterol levels, and previous research has found associations to thrombotic events. As such, further investigations may be warranted to explore the formation of procoagulant platelets as a possible biomarker for cardiovascular disease. 


\section{Acknowledgements}

Tack till alla er som på ett eller annat vis bidragit till att den här avhandlingen blivit till. Ett särskilt tack till,

Sofia Ramström, min huvudhandledare. För den här möjligheten. Jag har någon gång beskrivit dig som min forskningsmamma, det känns fortfarande som en passande beskrivning. Tack för den relation vi haft, vi har kunnat prata, tjafsa och vara oense, för att sedan komma överens om det bästa sättet att gå vidare. För att man alltid kan dyka upp med en fråga eller två. Tack också för alla roliga äventyr. Men ett äventyr där allt går precis enligt plan blir sällan bra historier efterăt, eller hur var det nu med Stonehenge?

Karin Öllinger, min biträdande handledare. För stöd, goda tips och kloka råd längs vägen. Med ett öga för detaljer och en ibland frustrerande petighet, som jag trots alltid är glad för i efterhand. Jag har lärt mig mycket av dig!

Mina medförfattare, Sofia, Karin, Nahreen Tynngård, Gösta Berlin, Magnus Grenegård, Ann-Charlotte Svensson-Holm och Eva Lindström.

Hela hemostaslabbet! Sofia, Tomas, Kerstin, Kjersti, Maria, Ankit, Lars, Niklas och Micke. För att ni delar med er av er kunskap inom hemostas, för sällskap och hjälp på och kring labbet, det är mycket roligare att labba när man är flera. För alla roliga upptåg både på och utanför jobbet, och för att man aldrig behöver dricka kaffe själv när man behöver en paus. Men framför allt TACK för att ni är ett så roligt gäng! Tack vare er har det känts roligt att gå till jobbet även de dagarna då själva jobbet varit desto mindre roligt! Thank you also to previous members of the lab!

Ankit for being such a good officemate!

Nahreen, för din hjälpsamhet i alla lägen, för ditt tålamod när jag ställt otaliga frågor om diverse olika metoder och trombocytkoncentrat, för ditt goda humör och trevliga sällskap.

Magnus Grenegård, för din entusiasm kring allt som rör trombocyter.

Tack till alla på plan 11 för trevliga luncher och fikaraster. För alla samtal om viktiga, oviktiga och ibland märkliga samtalsämnen!

Särskilt tack till Elvar, och Cecilia för peptalks och goda råd.

Forum Scientium, för trevliga och lärorika konferenser, resor och möten. 
Familj och vänner som gjort det möjligt att lägga forskningen åt sidan för en stund och göra något annat.

Malin Silverå-Ejneby. Vi träffades första dagen på Nolle-P och sedan dess har vi hängt ihop. Genom labbrapporter på kandidaten, basgrupper på mastern och allt som en doktorandtid innebär därefter. Tack för att du är dig själv i alla lägen och tack för allt ditt stöd och roliga upptåg längs vägen. Jag kan inte tänka mig hur det skulle gått utan dig!

Sara, när vi träffades hade vi svårt att ens förstå vad du sa. Tur att vi båda var envisa. Tack för välbehövliga pauser med allt från drinkkvällar till lekparkshäng.

Tack till 4V-tjejerna, Malin, Sara, Jessica, Sofia Klubb, Sofia (Nygårds) och Minna. Vi ses inte så ofta längre, men jag är så glad varje gång vi lyckas. Och till killarna, Mattias, Jonas, Erik och Eddie, utan er hade det inte varit samma sak.

Domfil: Malin, Kjersti, Erik, Cynthia, Emina, Liam, Stefan, Angelika, m.fl. för möjlighet att ventilera lite med någon som förstår sig på ens vardag och för alla trevliga kvällar tillsammans.

Malin Hultin Stål, för att du är en så fin vän! Det hinner allt för ofta gå för lång tid mellan gångerna, men när vi väl ses känns som att det var igår. Det känns bra att veta att du finns där, genom vått och torrt!

Maria, Robin, Kjersti, Anders, Emil, Frida, Klara, Fredde, för alla middagar, spelkvällar m.m., det kanske är dags snart igen? Emma och Linn, för roliga kvällar genom åren, med alldeles för mycket godis!

Min familj! Mamma och pappa som funnits där när jag behövt er. Mamma, min hjälte, jag vet att du hade varit stolt över mig. Jag önskar att du fått vara med mig hela vägen!

Min syster Klara, för bus och tandborstsamtal genom åren, för roliga utflykter hjälp och med lite av varje när det behövts. Vilken tur att du och Fredde också blev kvar i Linköping! Nu väntar nya äventyr och det ska bli roligt att följas åt på vägen.

Mina släktingar Barbro, Kenneth, Erik, Elisabeth, Håkan, Gun, Anne, Reino, Kennet, kusiner och kusinbarn.

Stefans familj: Thomas, Märtha, Bengt, Sandra och Robert som tagit emot mig så väl uppe i Ö-vik. Ni har verkligen blivit som en extra familj!

Till min närmsta familj: Stefan för att jag får dela min vardag med dig, genom vått och torrt. För att du stöttat mig på vägen, särskilt nu på slutet då det behövts som mest. Alfons, för att du förgyller mina dagar med din nyfikenhet, ditt bus, din envishet och dina kramar. Vår kommande familjemedlem, jag väntar med spänning på att få lära känna dig. Jag älskar er! 


\section{References}

1. Statistikdatabas för dödsorsaker [Internet]. 2018 [cited 2018-09-18]. Available from: http://www.socialstyrelsen.se/statistik/statistikdatabas/dodsorsaker.

2. Cramer E, Fontenay M: Platelets: Structure related to function; in: Robert Colman VM, Alexander Clowes, James George, Samuel Goldhabers: Hemostasis and thrombosis: Basic principles and clinical practice. $5^{\text {th }}$ ed. Place: Lippincott Williams \& Wilkins 2006.

3. Hillarp A, Dahlbäck B, Strandberg K: Koagulationsrubbningar; in: Nilsson-Ehle P, Berggren Söderlund M, Theodorsson Es: Laurells klinisk kemi i praktisk medicin. 9th ed. Place: Lund : Studentlitteratur 2012.

4. White JG: Chapter 7 - platelet structure; in: Michelson ADs: Platelets (third edition). Place: Academic Press 2013.

5. Heijnen HFG, Korporaal SJA: Platelet morphology and ultrastructure; in: Gresele P, Kleiman NS, Lopez JA, Page CPs: Platelets in thrombotic and non-thrombotic disorders: Pathophysiology, pharmacology and therapeutics: An update. Place: Springer International Publishing 2017.

6. Josefsson EC, Dowling MR, Lebois M, et al.: Chapter 3 - the regulation of platelet life span; in: Michelson ADs: Platelets (third edition). Place: Academic Press 2013.

7. Borges I, Sena I, Azevedo P, et al.: Lung as a niche for hematopoietic progenitors. Stem Cell Rev 2017; 13:567-574.

8. Italiano JE: Megakaryocyte development and platelet production; in: Gresele P, Kleiman NS, Lopez JA, Page CPs: Platelets in thrombotic and non-thrombotic disorders: Pathophysiology, pharmacology and therapeutics: An update. Place: Springer International Publishing 2017.

9. Nishimura S, Nagasaki M, Kunishima S, et al.: Il-1alpha induces thrombopoiesis through megakaryocyte rupture in response to acute platelet needs. $J$ Cell Biol 2015; 209:453-466.

10. Bevers EM, Comfurius P, Zwaal RF: Platelet procoagulant activity: Physiological significance and mechanisms of exposure. Blood Rev 1991; 5:146-154.

11. Hartwig JH: Chapter 8 - the platelet cytoskeleton; in: Michelson ADs: Platelets (third edition). Place: Academic Press 2013.

12. Flaumenhaft R: Chapter 18 - platelet secretion; in: Michelson ADs: Platelets (third edition). Place: Academic Press 2013.

13. Rendu F, Brohard-Bohn B: The platelet release reaction: Granules' constituents, secretion and functions. Platelets 2001; 12:261-273.

14. Sawada R, Lowe JB, Fukuda M: E-selectin-dependent adhesion efficiency of colonic carcinoma cells is increased by genetic manipulation of their cell surface lysosomal membrane glycoprotein-1 expression levels. J Biol Chem 1993; 268:12675-12681.

15. Reddy A, Caler EV, Andrews NW: Plasma membrane repair is mediated by ca(2+)-regulated exocytosis of lysosomes. Cell 2001; 106:157-169.

16. Clemetson KJ, Clemetson JM: Chapter 9 - platelet receptors; in: Michelson ADs: Platelets (third edition). Place: Academic Press 2013. 
17. Andrews RK, Berndt MC: Chapter 10 - the gpib-ix-v complex; in: Michelson ADs: Platelets (third edition). Place: Academic Press 2013.

18. Ruggeri ZM, Mendolicchio GL: Adhesion mechanisms in platelet function. Circ Res 2007; 100:1673-1685.

19. Nieswandt B, Pleines I, Bender M: Platelet adhesion and activation mechanisms in arterial thrombosis and ischaemic stroke. J Thromb Haemost 2011; 9 Suppl 1:92-104.

20. Bledzka K, Pesho MM, Ma Y-Q, et al.: Chapter 12 - integrin aiibß3; in: Michelson ADs: Platelets (third edition). Place: Academic Press 2013.

21. Pollitt AY, Hughes CE, Watson SP: Chapter 11 - gpvi and clec-2; in: Michelson ADs: Platelets (third edition). Place: Academic Press 2013.

22. Varga-Szabo D, Pleines I, Nieswandt B: Cell adhesion mechanisms in platelets. Arterioscler Thromb Vasc Biol 2008; 28:403-412.

23. Alberio L, Safa O, Clemetson KJ, et al.: Surface expression and functional characterization of alpha-granule factor $\mathrm{v}$ in human platelets: Effects of ionophore a23187, thrombin, collagen, and convulxin. Blood 2000; 95:16941702.

24. Ramstrom S, O'Neill S, Dunne E, et al.: Annexin v binding to platelets is agonist, time and temperature dependent. Platelets 2010; 21:289-296.

25. Bevers EM, Comfurius P, Zwaal RF: Changes in membrane phospholipid distribution during platelet activation. Biochim Biophys Acta 1983; 736:57-66.

26. Zhang P, Covic L, Kuliopulos A: Chapter 13 - protease-activated receptors; in: Michelson ADs: Platelets (third edition). Place: Academic Press 2013.

27. Ashby B: Platelet prostanoid receptors; in: Robert Colman VM, Alexander Clowes, James George, Samuel Goldhabers: Hemostasis and thrombosis: Basic principles and clinical practice. $5^{\text {th }}$ ed. Place: Lippincott Williams \& Wilkins 2006.

28. Cattaneo M: Chapter 14 - the platelet p2 receptors; in: Michelson ADs: Platelets (third edition). Place: Academic Press 2013.

29. Beaulieu LM, Freedman JE: Chapter 17 - inhibition of platelet function by the endothelium; in: Michelson ADs: Platelets (third edition). Place: Academic Press 2013.

30. Evangelista V, Smyth SS: Chapter 16 - interactions between platelets, leukocytes and the endothelium; in: Michelson ADs: Platelets (third edition). Place: Academic Press 2013.

31. Monroe DM, Hoffman M: What does it take to make the perfect clot? Arterioscler Thromb Vasc Biol 2006; 26:41-48.

32. Hemker HC, Al Dieri R, De Smedt E, et al.: Thrombin generation, a function test of the haemostatic-thrombotic system. Thromb Haemost 2006; 96:553-561.

33. Bock SC: Antithrombin iii and heparin cofactor ii; in: Robert Colman VM, Alexander Clowes, James George, Samuel Goldhabers: Hemostasis and thrombosis: Basic principles and clinical practice. $5^{\text {th }}$ ed. Place: Lippincott Williams \& Wilkins 2006.

34. Colman R, Clowes A, George J, et al.: Overview of hemostasis; in: Robert Colman VM, Alexander Clowes, James George, Samuel Goldhabers: Hemostasis and thrombosis: Basic principles and clinical practice. $5^{\text {th }}$ ed. Place: Lippincott Williams \& Wilkins 2006. 
35. Lee JY, Lee MY, Chung SM, et al.: Chemically induced platelet lysis causes vasoconstriction by release of serotonin. Toxicol Appl Pharmacol 1998; 149:235242.

36. Stalker TJ, Traxler EA, Wu J, et al.: Hierarchical organization in the hemostatic response and its relationship to the platelet-signaling network. Blood 2013; 121:1875-1885.

37. Stalker TJ, Welsh JD, Tomaiuolo M, et al.: A systems approach to hemostasis: 3 . Thrombus consolidation regulates intrathrombus solute transport and local thrombin activity. Blood 2014; 124:1824-1831.

38. Macfarlane RG: An enzyme cascade in the blood clotting mechanism, and its function as a biochemical amplifier. Nature 1964; 202:498-499.

39. Davie EW, Ratnoff OD: Waterfall sequence for intrinsic blood clotting. Science 1964; 145:1310-1312.

40. Colman R, VJ. M, Clowes A: Overview of coagulation, fibrinolysis, and their regulation; in: Robert Colman VM, Alexander Clowes, James George, Samuel Goldhabers: Hemostasis and thrombosis: Basic principles and clinical practice. 5th ed. Place: Lippincott Williams \& Wilkins 2006.

41. Nesheim ME, Taswell JB, Mann KG: The contribution of bovine factor $\mathrm{v}$ and factor va to the activity of prothrombinase. $J$ Biol Chem 1979; 254:10952-10962.

42. Mackman N: The role of tissue factor and factor viia in hemostasis. Anesth Analg 2009; 108:1447-1452.

43. Nesheim ME, Leurs J, Hendriks DF: Thrombin-activatable fibrinolysis inhibitor aka procarboxypeptidase u; in: Robert Colman VM, Alexander Clowes, James George, Samuel Goldhabers: Hemostasis and thrombosis: Basic principles and clinical practice. $5^{\text {th }}$ ed. Place: Lippincott Williams \& Wilkins 2006.

44. Webber AJ, Firkin BG: Two populations of platelets. Nature 1965; 205:1332.

45. Sims PJ, Wiedmer T: Unraveling the mysteries of phospholipid scrambling. Thromb Haemost 2001; 86:266-275.

46. Bevers EM, Williamson PL: Phospholipid scramblase: An update. FEBS Lett 2010; 584:2724-2730.

47. Suzuki J, Umeda M, Sims PJ, et al.: Calcium-dependent phospholipid scrambling by tmem16f. Nature 2010; 468:834-838.

48. Wolfs JL, Comfurius P, Rasmussen JT, et al.: Activated scramblase and inhibited aminophospholipid translocase cause phosphatidylserine exposure in a distinct platelet fraction. Cell Mol Life Sci 2005; 62:1514-1525.

49. Bevers EM, Comfurius P, van Rijn JL, et al.: Generation of prothrombinconverting activity and the exposure of phosphatidylserine at the outer surface of platelets. Eur J Biochem 1982; 122:429-436.

50. Bevers EM, Comfurius P, Hemker HC, et al.: On the clot-promoting activity of human platelets in a one-stage prothrombinase assay. Haemostasis 1982; 12:268-274.

51. Rosing J, van Rijn JL, Bevers EM, et al.: The role of activated human platelets in prothrombin and factor x activation. Blood 1985; 65:319-332.

52. Thiagarajan P, Tait JF: Binding of annexin v/placental anticoagulant protein i to platelets. Evidence for phosphatidylserine exposure in the procoagulant response of activated platelets. $J$ Biol Chem 1990; 265:17420-17423. 
53. Thiagarajan P, Tait JF: Collagen-induced exposure of anionic phospholipid in platelets and platelet-derived microparticles. J Biol Chem 1991; 266:2430224307.

54. Reutelingsperger CP, Kop JM, Hornstra G, et al.: Purification and characterization of a novel protein from bovine aorta that inhibits coagulation. Inhibition of the phospholipid-dependent factor-xa-catalyzed prothrombin activation, through a high-affinity binding of the anticoagulant to the phospholipids. Eur J Biochem 1988; 173:171-178.

55. Agbani EO, Cash J, Williams C, et al.: Phosphatidylserine exposure after vascular injury-platelet or endothelial. bioRxiv 2017.

56. Rosing J, Bevers EM, Comfurius P, et al.: Impaired factor $\mathrm{x}$ and prothrombin activation associated with decreased phospholipid exposure in platelets from a patient with a bleeding disorder. Blood 1985; 65:1557-1561.

57. Dachary-Prigent J, Freyssinet JM, Pasquet JM, et al.: Annexin v as a probe of aminophospholipid exposure and platelet membrane vesiculation: A flow cytometry study showing a role for free sulfhydryl groups. Blood 1993; 81:25542565 .

58. Dachary-Prigent J, Pasquet JM, Freyssinet JM, et al.: Calcium involvement in aminophospholipid exposure and microparticle formation during platelet activation: A study using ca2+-atpase inhibitors. Biochemistry 1995; 34:1162511634 .

59. Heemskerk JW, Vuist WM, Feijge MA, et al.: Collagen but not fibrinogen surfaces induce bleb formation, exposure of phosphatidylserine, and procoagulant activity of adherent platelets: Evidence for regulation by protein tyrosine kinasedependent ca2+ responses. Blood 1997; 90:2615-2625.

60. Sims PJ, Faioni EM, Wiedmer T, et al.: Complement proteins c5b-9 cause release of membrane vesicles from the platelet surface that are enriched in the membrane receptor for coagulation factor va and express prothrombinase activity. J Biol Chem 1988; 263:18205-18212.

61. Sims PJ, Wiedmer T, Esmon CT, et al.: Assembly of the platelet prothrombinase complex is linked to vesiculation of the platelet plasma membrane. Studies in scott syndrome: An isolated defect in platelet procoagulant activity. J Biol Chem 1989; 264:17049-17057.

62. Pasquet JM, Dachary-Prigent J, Nurden AT: Calcium influx is a determining factor of calpain activation and microparticle formation in platelets. Eur $J$ Biochem 1996; 239:647-654.

63. Briede JJ, Heemskerk JW, Hemker HC, et al.: Heterogeneity in microparticle formation and exposure of anionic phospholipids at the plasma membrane of single adherent platelets. Biochim Biophys Acta 1999; 1451:163-172.

64. Munnix IC, Kuijpers MJ, Auger J, et al.: Segregation of platelet aggregatory and procoagulant microdomains in thrombus formation: Regulation by transient integrin activation. Arterioscler Thromb Vasc Biol 2007; 27:2484-2490.

65. Agbani EO, van den Bosch MT, Brown E, et al.: Coordinated membrane ballooning and procoagulant spreading in human platelets. Circulation 2015; 132:1414-1424.

66. Dale GL, Remenyi G, Friese P: Quantitation of microparticles released from coated-platelets. $J$ Thromb Haemost 2005; 3:2081-2088. 
67. Tocchetti EV, Flower RL, Lloyd JV: Assessment of in vitro-generated platelet microparticles using a modified flow cytometric strategy. Thromb Res 2001; 103:47-55.

68. Bode AP, Hickerson DH: Characterization and quantitation by flow cytometry of membranous microparticles formed during activation of platelet suspensions with ionophore or thrombin. Platelets 2000; 11:259-271.

69. Siljander PR, Munnix IC, Smethurst PA, et al.: Platelet receptor interplay regulates collagen-induced thrombus formation in flowing human blood. Blood 2004; 103:1333-1341.

70. Kulkarni S, Jackson SP: Platelet factor xiii and calpain negatively regulate integrin alphaiibbeta3 adhesive function and thrombus growth. $J$ Biol Chem 2004; 279:30697-30706.

71. Dale GL, Friese P, Batar P, et al.: Stimulated platelets use serotonin to enhance their retention of procoagulant proteins on the cell surface. Nature 2002; 415:175-179.

72. Szasz R, Dale GL: Thrombospondin and fibrinogen bind serotonin-derivatized proteins on coat-platelets. Blood 2002; 100:2827-2831.

73. Mattheij NJ, Gilio K, van Kruchten R, et al.: Dual mechanism of integrin alphaiibbeta3 closure in procoagulant platelets. $J$ Biol Chem 2013; 288:1332513336.

74. Abaeva AA, Canault M, Kotova YN, et al.: Procoagulant platelets form an alphagranule protein-covered "cap" on their surface that promotes their attachment to aggregates. J Biol Chem 2013; 288:29621-29632.

75. Shattil SJ, Hoxie JA, Cunningham M, et al.: Changes in the platelet membrane glycoprotein iib.Iiia complex during platelet activation. $J$ Biol Chem 1985; 260:11107-11114.

76. Jobe SM, Leo L, Eastvold JS, et al.: Role of fcrgamma and factor xiiia in coated platelet formation. Blood 2005; 106:4146-4151.

77. Mattheij NJ, Swieringa F, Mastenbroek TG, et al.: Coated platelets function in platelet-dependent fibrin formation via integrin alphaiibbeta3 and transglutaminase factor xiii. Haematologica 2016; 101:427-436.

78. Topalov NN, Kotova YN, Vasil'ev SA, et al.: Identification of signal transduction pathways involved in the formation of platelet subpopulations upon activation.

Br J Haematol 2012; 157:105-115.

79. Laudano AP, Doolittle RF: Studies on synthetic peptides that bind to fibrinogen and prevent fibrin polymerization. Structural requirements, number of binding sites, and species differences. Biochemistry 1980; 19:1013-1019.

80. Michelson AD: Platelet activation by thrombin can be directly measured in whole blood through the use of the peptide gprp and flow cytometry: Methods and clinical applications. Blood Coagul Fibrinolysis 1994; 5:121-131.

81. Artemenko EO, Yakimenko AO, Pichugin AV, et al.: Calpain-controlled detachment of major glycoproteins from the cytoskeleton regulates adhesive properties of activated phosphatidylserine-positive platelets. Biochem $J$ 2016; 473:435-448.

82. Batar P, Dale GL: Simultaneous engagement of thrombin and fc gamma riia receptors results in platelets expressing high levels of procoagulant proteins. $J$ Lab Clin Med 2001; 138:393-402. 
83. Heemskerk JWM, Cosemans JMEM, van der Meijden PEJ: Platelets and coagulation; in: Gresele P, Kleiman NS, Lopez JA, Page CPs: Platelets in thrombotic and non-thrombotic disorders: Pathophysiology, pharmacology and therapeutics: An update. Place: Springer International Publishing 2017.

84. Harper AGS, Sage SO: Platelet signalling: Calcium; in: Gresele P, Kleiman NS, Lopez JA, Page CPs: Platelets in thrombotic and non-thrombotic disorders: Pathophysiology, pharmacology and therapeutics: An update. Place: Springer International Publishing 2017.

85. Gilio K, van Kruchten R, Braun A, et al.: Roles of platelet stim1 and orai1 in glycoprotein vi- and thrombin-dependent procoagulant activity and thrombus formation. $J$ Biol Chem 2010; 285:23629-23638.

86. Harper MT, Londono JE, Quick K, et al.: Transient receptor potential channels function as a coincidence signal detector mediating phosphatidylserine exposure. Sci Signal 2013; 6:ra5o.

87. Remenyi G, Szasz R, Friese P, et al.: Role of mitochondrial permeability transition pore in coated-platelet formation. Arterioscler Thromb Vasc Biol 2005; 25:467-471.

88. Jobe SM, Wilson KM, Leo L, et al.: Critical role for the mitochondrial permeability transition pore and cyclophilin d in platelet activation and thrombosis. Blood 2008; 111:1257-1265.

89. Choo HJ, Saafir TB, Mkumba L, et al.: Mitochondrial calcium and reactive oxygen species regulate agonist-initiated platelet phosphatidylserine exposure. Arterioscler Thromb Vasc Biol 2012; 32:2946-2955.

90. Kholmukhamedov A, Janecke R, Choo HJ, et al.: The mitochondrial calcium uniporter regulates procoagulant platelet formation. J Thromb Haemost 2018.

91. Obydennyy SI, Sveshnikova AN, Ataullakhanov FI, et al.: Dynamics of calcium spiking, mitochondrial collapse and phosphatidylserine exposure in platelet subpopulations during activation. $J$ Thromb Haemost 2016; 14:1867-1881.

92. Fox JE, Reynolds CC, Austin CD: The role of calpain in stimulus-response coupling: Evidence that calpain mediates agonist-induced expression of procoagulant activity in platelets. Blood 1990; 76:2510-2519.

93. Fox JE, Austin CD, Reynolds CC, et al.: Evidence that agonist-induced activation of calpain causes the shedding of procoagulant-containing microvesicles from the membrane of aggregating platelets. $J$ Biol Chem 1991; 266:13289-13295.

94. Liu F, Gamez G, Myers DR, et al.: Mitochondrially mediated integrin alphaiibbeta3 protein inactivation limits thrombus growth. $J$ Biol Chem 2013; 288:30672-30681.

95. Du X, Saido TC, Tsubuki S, et al.: Calpain cleavage of the cytoplasmic domain of the integrin beta 3 subunit. $J$ Biol Chem 1995; 270:26146-26151.

96. Tynngard N, Lindahl T, Ramstrom S, et al.: Effects of different blood components on clot retraction analysed by measuring elasticity with a free oscillating rheometer. Platelets 2006; 17:545-554.

97. Mattheij NJ, Braun A, van Kruchten R, et al.: Survival protein anoctamin-6 controls multiple platelet responses including phospholipid scrambling, swelling, and protein cleavage. FASEB $J$ 2016; 30:727-737. 
98. van Kruchten R, Mattheij NJ, Saunders C, et al.: Both tmem16f-dependent and tmem16f-independent pathways contribute to phosphatidylserine exposure in platelet apoptosis and platelet activation. Blood 2013; 121:1850-1857.

99. Yang H, Kim A, David T, et al.: Tmem16f forms a ca2+-activated cation channel required for lipid scrambling in platelets during blood coagulation. Cell 2012; 151:111-122.

100. Tian Y, Schreiber R, Kunzelmann K: Anoctamins are a family of ca2+-activated cl- channels. $J$ Cell Sci 2012; 125:4991-4998.

101. Dale GL, Friese P, Hynes LA, et al.: Demonstration that thiazole-orange-positive platelets in the dog are less than 24 hours old. Blood 1995; 85:1822-1825.

102. Angenieux C, Maitre B, Eckly A, et al.: Time-dependent decay of mrna and ribosomal rna during platelet aging and its correlation with translation activity. PLoS One 2016; 11:e0148064.

103. Dale GL: Platelet kinetics. Curr Opin Hematol 1997; 4:330-334.

104. Thompson CB, Jakubowski JA, Quinn PG, et al.: Platelet size and age determine platelet function independently. Blood 1984; 63:1372-1375.

105. Peng J, Friese P, Heilmann E, et al.: Aged platelets have an impaired response to thrombin as quantitated by p-selectin expression. Blood 1994; 83:161-166.

106. Lador A, Leshem-Lev D, Spectre G, et al.: Characterization of surface antigens of reticulated immature platelets. $J$ Thromb Thrombolysis 2017; 44:291-297.

107. Reddy EC, Wang H, Bang KWA, et al.: Young steady-state rabbit platelets do not have an enhanced capacity to expose procoagulant phosphatidylserine. Platelets 2018; 29:27-33.

108. Katus MC, Szczepiorkowski ZM, Dumont LJ, et al.: Safety of platelet transfusion: Past, present and future. Vox Sang 2014; 107:103-113.

109. van der Meer PF: Platelet concentrates, from whole blood or collected by apheresis? Transfus Apher Sci 2013; 48:129-131.

110. Devine DV, Serrano K: The platelet storage lesion. Clin Lab Med 2010; 30:475487.

111. Kumar A, Mhaskar R, Grossman BJ, et al.: Platelet transfusion: A systematic review of the clinical evidence. Transfusion 2015; 55:1116-1127; quiz 1115.

112. Wandt H, Schafer-Eckart K, Greinacher A: Platelet transfusion in hematology, oncology and surgery. Dtsch Arztebl Int 2014; 111:809-815.

113. Holbro A, Infanti L, Sigle J, et al.: Platelet transfusion: Basic aspects. Swiss Med Wkly 2013; 143:w13885.

114. Garraud O, Cognasse F, Tissot JD, et al.: Improving platelet transfusion safety: Biomedical and technical considerations. Blood Transfus 2016; 14:109-122.

115. Caram-Deelder C, Kreuger AL, Jacobse J, et al.: Effect of platelet storage time on platelet measurements: A systematic review and meta-analyses. Vox Sang 2016; 111:374-382.

116. Ohto H, Nollet KE: Overview on platelet preservation: Better controls over storage lesion. Transfus Apher Sci 2011; 44:321-325.

117. Kehrel B E, F. BM: State of the art in platelet function testing. Transfus Med Hemother 2013; 40:73-86.

118. Holme S: Storage and quality assessment of platelets. Vox Sang 1998; 74 Suppl 2:207-216. 
119. Cardigan R, Turner C, Harrison P: Current methods of assessing platelet function: Relevance to transfusion medicine. Vox Sang 2005; 88:153-163.

120. Cauwenberghs S, van Pampus E, Curvers J, et al.: Hemostatic and signaling functions of transfused platelets. Transfus Med Rev 2007; 21:287-294.

121. Panzer S, Jilma P: Methods for testing platelet function for transfusion medicine. Vox Sang 2011; 101:1-9.

122. Rinder HM, Smith BR: In vitro evaluation of stored platelets: Is there hope for predicting posttransfusion platelet survival and function? Transfusion 2003; 43:2-6.

123. Murphy S, Gardner FH: Effect of storage temperature on maintenance of platelet viability--deleterious effect of refrigerated storage. N Engl J Med 1969; 280:1094-1098.

124. Slichter SJ, Harker LA: Preparation and storage of platelet concentrates. Ii. Storage variables influencing platelet viability and function. Br J Haematol 1976; 34:403-419.

125. Curvers J, van Pampus EC, Feijge MA, et al.: Decreased responsiveness and development of activation markers of plts stored in plasma. Transfusion 2004; 44:49-58.

126. Triulzi DJ, Assmann SF, Strauss RG, et al.: The impact of platelet transfusion characteristics on posttransfusion platelet increments and clinical bleeding in patients with hypoproliferative thrombocytopenia. Blood 2012; 119:5553-5562.

127. MacLennan S, Harding $\mathrm{K}$, Llewelyn $\mathrm{C}$, et al.: A randomized noninferiority crossover trial of corrected count increments and bleeding in thrombocytopenic hematology patients receiving 2- to 5-versus 6- or 7-day-stored platelets. Transfusion 2015; 55:1856-1865; quiz 1855.

128. Murphy S, Sayar SN, Gardner FH: Storage of platelet concentrates at 22 degrees c. Blood 1970; 35:549-557.

129. Bertolini F, Murphy S: A multicenter inspection of the swirling phenomenon in platelet concentrates prepared in routine practice. Biomedical excellence for safer transfusion (best) working party of the international society of blood transfusion. Transfusion 1996; 36:128-132.

130. Holme S, Bode A, Heaton WA, et al.: Improved maintenance of platelet in vivo viability during storage when using a synthetic medium with inhibitors. $J L a b$ Clin Med 1992; 119:144-150.

131. Holme S, Sweeney JD, Sawyer S, et al.: The expression of p-selectin during collection, processing, and storage of platelet concentrates: Relationship to loss of in vivo viability. Transfusion 1997; 37:12-17.

132. Dumont LJ, AuBuchon JP, Whitley P, et al.: Seven-day storage of single-donor platelets: Recovery and survival in an autologous transfusion study. Transfusion 2002; 42:847-854.

133. Michelson AD, Barnard MR, Hechtman $\mathrm{HB}$, et al.: In vivo tracking of platelets: Circulating degranulated platelets rapidly lose surface p-selectin but continue to circulate and function. Proc Natl Acad Sci U S A 1996; 93:11877-11882.

134. Berger G, Hartwell DW, Wagner DD: P-selectin and platelet clearance. Blood 1998; 92:4446-4452.

135. Lordkipanidze M: Platelet function tests. Semin Thromb Hemost 2016; 42:258267. 
136. May JA, Heptinstall S: Effects of anticoagulants used during blood collection on human platelet function. Methods Mol Biol 2004; 272:3-11.

137. Ramstrom S, Sodergren AL, Tynngard N, et al.: Platelet function determined by flow cytometry: New perspectives? Semin Thromb Hemost 2016; 42:268-281.

138. Schneider DJ, Tracy PB, Mann KG, et al.: Differential effects of anticoagulants on the activation of platelets ex vivo. Circulation 1997; 96:2877-2883.

139. Packham MA, Bryant NL, Guccione MA, et al.: Effect of the concentration of ca2+ in the suspending medium on the responses of human and rabbit platelets to aggregating agents. Thromb Haemost 1989; 62:968-976.

140. Stafford NP, Pink AE, White AE, et al.: Mechanisms involved in adenosine triphosphate--induced platelet aggregation in whole blood. Arterioscler Thromb Vasc Biol 2003; 23:1928-1933.

141. Chapman K, Favaloro EJ: Time dependent reduction in platelet aggregation using the multiplate analyser and hirudin blood due to platelet clumping. Platelets 2018; 29:305-308.

142. Morton LF, Hargreaves PG, Farndale RW, et al.: Integrin alpha 2 beta 1independent activation of platelets by simple collagen-like peptides: Collagen tertiary (triple-helical) and quaternary (polymeric) structures are sufficient alone for alpha 2 beta 1-independent platelet reactivity. Biochem $J$ 1995; 306 ( Pt 2):337-344.

143. Hui KY, Jakubowski JA, Wyss VL, et al.: Minimal sequence requirement of thrombin receptor agonist peptide. Biochem Biophys Res Commun 1992; 184:790-796.

144. Hollenberg MD, Saifeddine M: Proteinase-activated receptor 4 (par4): Activation and inhibition of rat platelet aggregation by par4-derived peptides. Can J Physiol Pharmacol 2001; 79:439-442.

145. Born GV: Aggregation of blood platelets by adenosine diphosphate and its reversal. Nature 1962; 194:927-929.

146. O'Brien JR: Platelet aggregation: Part ii some results from a new method of study. J Clin Pathol 1962; 15:452-455.

147. Paniccia R, Priora R, Liotta AA, et al.: Platelet function tests: A comparative review. Vasc Health Risk Manag 2015; 11:133-148.

148. Gresele P, Falcinelli E, Bury L: Laboratory diagnosis of clinically relevant platelet function disorders. Int J Lab Hematol 2018; 40 Suppl 1:34-45.

149. Harrison P, Lordkipanidzé M: Chapter 26 - clinical tests of platelet function; in: Michelson ADs: Platelets (third edition). Place: Academic Press 2013.

150. Hayward CPM, Moffat KA: Chapter 28 - platelet aggregation; in: Michelson ADs: Platelets (third edition). Place: Academic Press 2013.

151. Picker SM: In-vitro assessment of platelet function. Transfus Apher Sci 2011; 44:305-319.

152. Hemker HC, Giesen P, AlDieri R, et al.: The calibrated automated thrombogram (cat): A universal routine test for hyper- and hypocoagulability. Pathophysiol Haemost Thromb 2002; 32:249-253.

153. Al Dieri R, de Laat B, Hemker HC: Thrombin generation: What have we learned? Blood Rev 2012; 26:197-203.

154. Castoldi E, Rosing J: Thrombin generation tests. Thromb Res 2011; 127 Suppl 3:S21-25. 
155. Hansson KM, Tengvall P, Lundstrom I, et al:: Surface plasmon resonance and free oscillation rheometry in combination: A useful approach for studies on haemostasis and interactions between whole blood and artificial surfaces. Biosens Bioelectron 2002; 17:747-759.

156. Ranby M, Ramstrom S, Svensson PO, et al.: Clotting time by free oscillation rheometry and visual inspection and a viscoelastic description of the clotting phenomenon. Scand J Clin Lab Invest 2003; 63:397-406.

157. Ramström S. The role of platelets in whole blood coagulation [Thesis (Ph.D.) Linköping University, 2003.]. Linköping, Sweden: Linköping University; 2003.

158. Ramstrom S, Ranby M, Lindahl TL: Effects of inhibition of p2y(1) and p2y(12) on whole blood clotting, coagulum elasticity and fibrinolysis resistance studied with free oscillation rheometry. Thromb Res 2003; 109:315-322.

159. Nilsson CU, Tynngard N, Reinstrup P, et al.: Monitoring fibrinolysis in whole blood by viscoelastic instruments: A comparison of rotem and reorox. Scand $J$ Clin Lab Invest 2013; 73:457-465.

160. Ramstrom S: Clotting time analysis of citrated blood samples is strongly affected by the tube used for blood sampling. Blood Coagul Fibrinolysis 2005; 16:447452.

161. Carter NP, Meyer EW: Introduction to the principles of flow cytometry; in: Ormerod MGs: Flow cytometry : A practical approach. Place: IRL Press at Oxford University Press 1990.

162. Göttlinger C, Mechtold B, Radbruch A: Operation of a flow cytometer; in: Radbruch As: Flow cytometry and cell sorting. Place: Springer Berlin Heidelberg 1992.

163. Adan A, Alizada G, Kiraz Y, et al.: Flow cytometry: Basic principles and applications. Crit Rev Biotechnol 2017; 37:163-176.

164. BeckmanCoulter. Instruction for use gallios flow cytometer. Brea, USA2015.

165. Shattil SJ, Cunningham M, Hoxie JA: Detection of activated platelets in whole blood using activation-dependent monoclonal antibodies and flow cytometry. Blood 1987; 70:307-315.

166. Pasalic L: Assessment of platelet function in whole blood by flow cytometry; in: Favaloro EJ, Lippi Gs: Hemostasis and thrombosis: Methods and protocols. Place: Springer New York 2017.

167. Arraud N, Gounou C, Turpin D, et al.: Fluorescence triggering: A general strategy for enumerating and phenotyping extracellular vesicles by flow cytometry. Cytometry A 2016; 89:184-195.

168. van der Pol E, Boing AN, Gool EL, et al.: Recent developments in the nomenclature, presence, isolation, detection and clinical impact of extracellular vesicles. $J$ Thromb Haemost 2016; 14:48-56.

169. Berny-Lang MA, Frelinger AL, Barnard MR, et al.: Chapter 29 - flow cytometry; in: Michelson ADs: Platelets (third edition). Place: Academic Press 2013.

170. Lacroix R, Robert S, Poncelet $\mathrm{P}$, et al.: Overcoming limitations of microparticle measurement by flow cytometry. Semin Thromb Hemost 2010; 36:807-818.

171. Israels SJ, McMillan EM, Robertson C, et al.: The lysosomal granule membrane protein, lamp-2, is also present in platelet dense granule membranes. Thromb Haemost 1996; 75:623-629. 
172. Nishibori M, Cham B, McNicol A, et al.: The protein cd63 is in platelet dense granules, is deficient in a patient with hermansky-pudlak syndrome, and appears identical to granulophysin. J Clin Invest 1993; 91:1775-1782.

173. Andree HA, Reutelingsperger CP, Hauptmann R, et al.: Binding of vascular anticoagulant alpha (vac alpha) to planar phospholipid bilayers. J Biol Chem 1990; 265:4923-4928.

174. Shi J, Heegaard CW, Rasmussen JT, et al.: Lactadherin binds selectively to membranes containing phosphatidyl-l-serine and increased curvature. Biochim Biophys Acta 2004; 1667:82-90.

175. Dasgupta SK, Guchhait P, Thiagarajan P: Lactadherin binding and phosphatidylserine expression on cell surface-comparison with annexin a5. Transl Res 2006; 148:19-25.

176. Albanyan AM, Murphy MF, Rasmussen JT, et al.: Measurement of phosphatidylserine exposure during storage of platelet concentrates using the novel probe lactadherin: A comparison study with annexin v. Transfusion 2009; 49:99-107.

177. Lindahl TL, Festin R, Larsson A: Studies of fibrinogen binding to platelets by flow cytometry: An improved method for studies of platelet activation. Thromb Haemost 1992; 68:221-225.

178. Pham NA, Robinson BH, Hedley DW: Simultaneous detection of mitochondrial respiratory chain activity and reactive oxygen in digitonin-permeabilized cells using flow cytometry. Cytometry 2000; 41:245-251.

179. MolecularProbes: Probes for membrane potential; in: The molecular probes® handbook - a guide to fluorescent probes and labeling technologies. Place: 2010.

180. Hulspas R, O'Gorman MR, Wood BL, et al.: Considerations for the control of background fluorescence in clinical flow cytometry. Cytometry B Clin Cytom 2009; 76:355-364.

181. Maecker HT, Trotter J: Flow cytometry controls, instrument setup, and the determination of positivity. Cytometry A 2006; 69:1037-1042.

182. Schmitz G, Rothe G, Ruf A, et al.: European working group on clinical cell analysis: Consensus protocol for the flow cytometric characterisation of platelet function. Thromb Haemost 1998; 79:885-896.

183. Zieger B: Defects of platelet granules and secretion; in: Gresele P, Kleiman NS, Lopez JA, Page CPs: Platelets in thrombotic and non-thrombotic disorders: Pathophysiology, pharmacology and therapeutics: An update. Place: Springer International Publishing 2017.

184. Ciferri S, Emiliani C, Guglielmini G, et al.: Platelets release their lysosomal content in vivo in humans upon activation. Thromb Haemost 2000; 83:157-164.

185. Schoenwaelder SM, Yuan Y, Josefsson EC, et al.: Two distinct pathways regulate platelet phosphatidylserine exposure and procoagulant function. Blood 2009; 114:663-666.

186. Jackson SP, Schoenwaelder SM: Procoagulant platelets: Are they necrotic? Blood 2010; 116:2011-2018.

187. Bevers EM, Williamson PL: Getting to the outer leaflet: Physiology of phosphatidylserine exposure at the plasma membrane. Physiol Rev 2016; 96:605-645. 
188. Hoffmann JJ: Reticulated platelets: Analytical aspects and clinical utility. Clin Chem Lab Med 2014; 52:1107-1117.

189. Perrotta PL, Parsons J, Rinder HM, et al.: Chapter 62 - platelet transfusion medicine; in: Michelson ADs: Platelets (third edition). Place: Academic Press 2013.

190. Rand ML, Packham MA, Mustard JF: Survival of density subpopulations of rabbit platelets: Use of 51cr-or 111in-labeled platelets to measure survival of least dense and most dense platelets concurrently. Blood 1983; 61:362-367.

191. Karpatkin S: Heterogeneity of human platelets. Vi. Correlation of platelet function with platelet volume. Blood 1978; 51:307-316.

192. Thompson CB, Love DG, Quinn PG, et al.: Platelet size does not correlate with platelet age. Blood 1983; 62:487-494.

193. Thompson CB, Jakubowski JA: The pathophysiology and clinical relevance of platelet heterogeneity. Blood 1988; 72:1-8.

194. Jackson SR, Carter JM: Platelet volume: Laboratory measurement and clinical application. Blood Rev 1993; 7:104-113.

195. Braekkan SK, Mathiesen EB, Njolstad I, et al.: Mean platelet volume is a risk factor for venous thromboembolism: The tromso study, tromso, norway. $J$ Thromb Haemost 2010; 8:157-162.

196. Klovaite J, Benn M, Yazdanyar S, et al.: High platelet volume and increased risk of myocardial infarction: 39,531 participants from the general population. $J$ Thromb Haemost 2011; 9:49-56.

197. Jobe S: Platelet heterogeneity; in: Gresele P, Kleiman NS, Lopez JA, Page CPs: Platelets in thrombotic and non-thrombotic disorders: Pathophysiology, pharmacology and therapeutics: An update. Place: Springer International Publishing 2017.

198. O'Malley T, Ludlam CA, Fox KA, et al.: Measurement of platelet volume using a variety of different anticoagulant and antiplatelet mixtures. Blood Coagul Fibrinolysis 1996; 7:431-436.

199. Södergren A, Ramström S: Abstracts isth: Platelet reactivity and receptor density in platelets with different mpv. Research and Practice in Thrombosis and Haemostasis 2017; 1:1-1451.

200. Dale GL: Coated-platelets: An emerging component of the procoagulant response. J Thromb Haemost 2005; 3:2185-2192.

201. Prodan CI, Joseph PM, Vincent AS, et al.: Coated-platelets in ischemic stroke: Differences between lacunar and cortical stroke. J Thromb Haemost 2008; 6:609-614.

202. Prodan CI, Vincent AS, Dale GL: Coated-platelet levels are elevated in patients with transient ischemic attack. Transl Res 2011; 158:71-75.

203. Pasalic L, Wing-Lun E, Lau JK, et al.: Novel assay demonstrates that coronary artery disease patients have heightened procoagulant platelet response. $J$ Thromb Haemost 2018; 16:1198-1210.

204. Prodan CI, Vincent AS, Padmanabhan R, et al.: Coated-platelet levels are low in patients with spontaneous intracerebral hemorrhage. Stroke 2009; 40:25782580 . 
205. Prodan CI, Vincent AS, Dale GL: Coated platelet levels correlate with bleed volume in patients with spontaneous intracerebral hemorrhage. Stroke 2010; 41:1301-1303.

206. Prodan CI, Stoner JA, Dale GL: Lower coated-platelet levels are associated with increased mortality after spontaneous intracerebral hemorrhage. Stroke 2015; 46:1819-1825.

207. Prodan CI, Ross ED, Stoner JA, et al.: Coated-platelet levels and progression from mild cognitive impairment to alzheimer disease. Neurology 2011; 76:247252.

208. Alberio L, Ravanat C, Hechler B, et al.: Delayed-onset of procoagulant signalling revealed by kinetic analysis of coat platelet formation. Thromb Haemost 2017; 117:1101-1114.

209. Wang N, Tall AR: Cholesterol in platelet biogenesis and activation. Blood 2016; 127:1949-1953.

210. Sadowitz B, Maier KG, Gahtan V: Basic science review: Statin therapy--part i: The pleiotropic effects of statins in cardiovascular disease. Vasc Endovascular Surg 2010; 44:241-251.

211. Shiraishi M, Tamura K, Egoshi M, et al.: Cholesterol enrichment of rabbit platelets enhances the ca(2+) entry pathway induced by platelet-derived secondary feedback agonists. Life Sci 2013; 92:838-844.

212. Shiraishi M, Tani E, Miyamoto A: Modulation of rabbit platelet aggregation and calcium mobilization by platelet cholesterol content. $J$ Vet Med Sci 2010; 72:285292.

213. Wei H, Malcor JM, Harper MT: Lipid rafts are essential for release of phosphatidylserine-exposing extracellular vesicles from platelets. Sci Rep 2018; 8:9987.

214. Aoki I, Aoki N, Kawano K, et al.: Platelet-dependent thrombin generation in patients with hyperlipidemia. J Am Coll Cardiol 1997; 30:91-96. 


\section{Papers}

The papers associated with this thesis have been removed for copyright reasons. For more details about these see:

http://urn.kb.se/resolve?urn=urn:nbn:se:liu:diva-152280 